\title{
OBRAZ UDÁLOSTÍ TŘICETILETÉ VÁLKY NA CHRUDIMSKU. KORELACE ARCHEOLOGICKÝCH A HISTORICKÝCH PRAMENŮ
}

\author{
JAN MUSIL - PETR NETOLICKÝ - MICHAL PREUSZ
}

\begin{abstract}
Abstrakt: Jak vyplývá ze současného stavu poznáni obdobi třicetileté války ve východočeském prostoru (konkrétně na Chrudimsku a Pardubicku), jedná se o region s velkým informačním potenciálem. Ačkoliv na Chrudimsku a Pardubicku na rozdil od západočeského či jihomoravského prostoru chybi hmotné doklady velkých bojišt' nebo pozůstatků obléhacich prací, můžeme zde diky tranzitni pozici sledovaného územi poměrně dobře dokumentovat napřiklad změny venkovského osidlení, výrazné destrukčni horizonty ve městech - doplňované nálezy keramických dýmek a pohyby menšich vojenských kontingentů doplněné dislokaci známých mincovnich depotů.
\end{abstract}

Klíčová slova: východni Čechy - raný novověk - třicetiletá válka - zaniklá vesnice - město - depot.

The events of the Thirty Years' War in the Chrudim region. Correlation of archaeological and historical sources

\begin{abstract}
As follows from the current state of knowledge of the Thirty Years' War period in eastern Bohemia (more precisely the Chrudim and Pardubice regions), this area has a great information potential. Although the Chrudim and Pardubice regions lack, in contrast to western Bohemia and southern Moravia, the material evidence of large battlefields and the remains of siege structures, the transit position of the area enables to document, for example, the changes in rural settlement, distinct destruction horizons in towns supplemented with finds of ceramic pipes, and the movements of small military contingents accompanied by the dislocation of well-known coin depots.
\end{abstract}

Key words: eastern Bohemia - early modern age - Thirty Years' War-deserted village - town-depot.

\section{1 Úvod}

Třicetiletá válka představovala poslední z velkých náboženských konfliktů mezi katolíky a protestanty, z jejíchž následků se české země vzpamatovávaly po zbytek 17. století. Nejinak tomu bylo i na Chrudimsku.

Pro potřeby předložené studie chápeme Chrudimsko v širším slova smyslu jako území bývalého okresu Chrudim. Hranice novodobého okresu se však oproti středověkému či raně novověkému vymezení někdejšího kraje Chrudimského výrazně lišila. Kraje se konstituovaly někdy na přelomu 13. a 14. století (AČ XXXI, s. XVII), během 14. století se staly správními jednotkami a nahradily tak původní hradskou soustavu (základní práce o podobě, vymezení a změnách krajů - srov. Novotný 1937, 288, 319, 390, 396; Sedláček 1921; Janák-Hledíková 1989, 76-77; MalýSivák 1993, 60-65). Jádrem našeho zájmového území byl pochopitelně Chrudimský kraj, který na západě sousedil s krajem Č́slavským, na severu s krajem Hradeckým a na východě s krajem Mýtským, který ještě v 15. století pohltil Chrudimský kraj (Teplý 1995, 12, pozn. 11). Novodobý okres Chrudim se rozkládá v jihozápadní části pardubického regionu s pahorkatinným až vrchovinovitým povrchem. Území zhruba trojúhelníkovitého tvaru sousedí na severu s okresem Pardubice, na západě se Středočeským krajem (okr. Kutná Hora), na jihu s krajem Vysočina (okr. Žd'ár nad Sázavou a Havlíčkův Brod) a na východě s okresy Ústí nad Orlicí a Svitavy. Pro účely tohoto článku mírně rozšíŕíme tuto oblast na Pardubicko a Přeloučsko (obr. 1).

\section{Přírodní podmínky}

Území Chrudimska se dělí na plochou severní a severovýchodní část tvořenou Chrudimskou tabulí a vyšší jihozápadní a jižní část př́slušnou k Železným horám a k severnímu okraji Žd'árských vrchů. Hlavní řekou regionu je Chrudimka, která společně s řekami Krounkou a Novohradkou vytváří hluboce zaříznutá údolí. Z regionálně geologického hlediska náleží území 

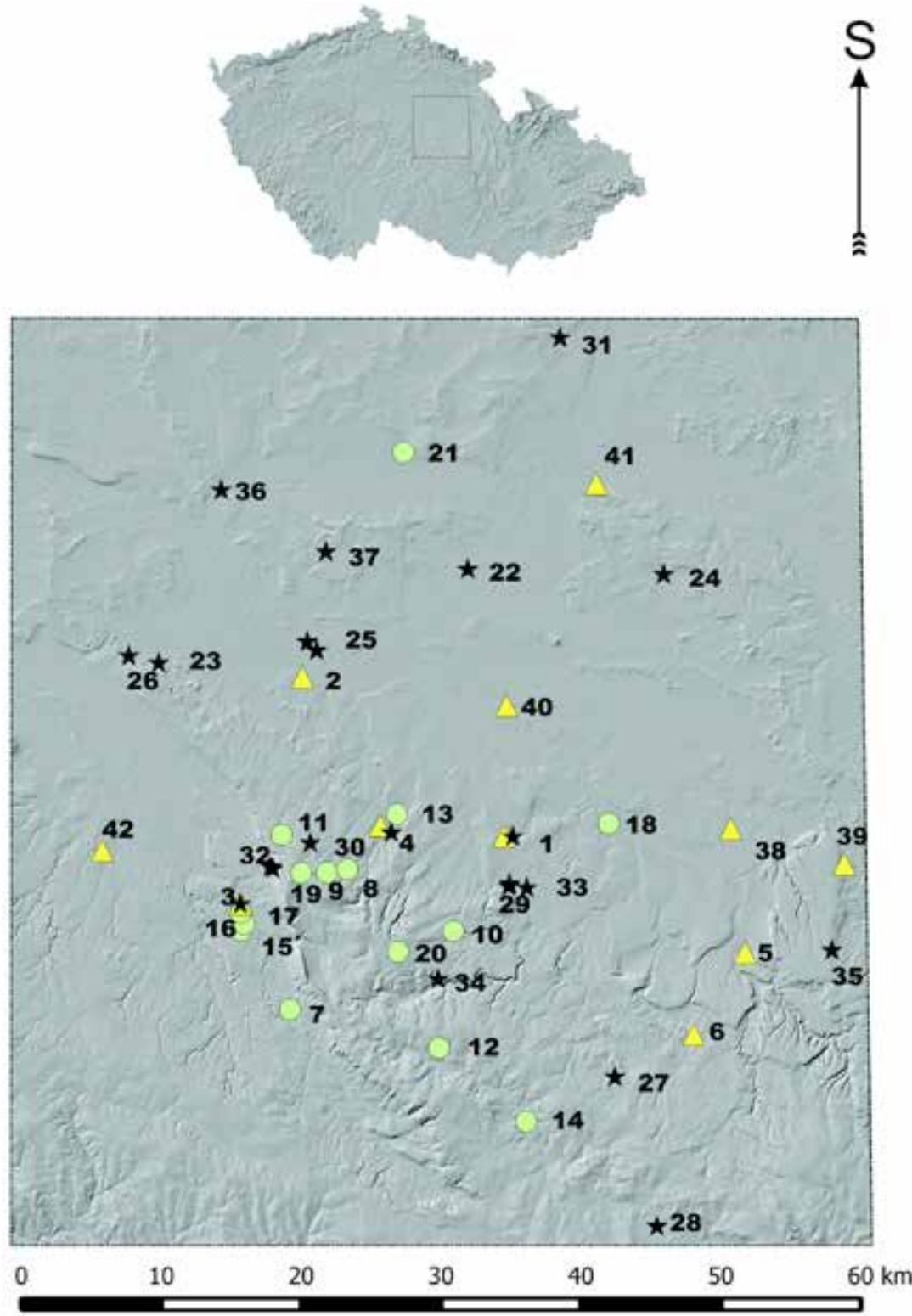

Obr. 1. Archeologické lokality zmiňované v textu. Trojúhelníky označují města a městečka, kolečka zaniklé vsi a hvězdičky depoty. 1 - Chrudim (okr. Chrudim); 2 - Přelouč (okr. Pardubice); 3 - Ronov nad Doubravou (okr. Chrudim); 4 - Heřmanův Městec (okr. Chrudim); 5 - Luže (okr. Chrudim); 6 - Skuteč (okr. Chrudim); 7 - ZSV Bolešov (k. ú. Spačice, okr. Chrudim); 8 - ZSV Drbohlavy (k. ú. Bošov, okr. Chrudim); 9 - ZSV Hody (k. ú. Vyžice, okr. Chrudim); 10 - Lipina (okr. Chrudim); 11 - ZSV Luhy (k. ú. Březinka u Hošt’alovic, okr. Chrudim); 12 - ZSV Máslovanky (k. ú. Horní Bradlo?, okr. Chrudim); 13 - tvrz, dvůr a ZSV Mrdice (k. ú. Heřmanův Městec, okr. Chrudim); 14 - Svatý Mikuláš (okr. Chrudim); 15 -ZSV Stusyně (k. ú. Ronov nad Doubravou, okr. Chrudim); 16 - ZSV Protivany (k. ú. Ronov nad Doubravou, okr. Chrudim); 17 - tvrz, dvůr a ZSV Suchotlesky (k. ú. Ronov nad Doubravou, okr. Chrudim); 18 - ZSV Třtí (k. ú. Vejvanovice?, okr. Chrudim); 19 - ZSV Záhuby (k. ú. Jetonice?, okr. Chrudim); 20 - ZSV Zlatník (k. ú. Hrbokov, okr. Chrudim); 21 - neznámá ves či dvůr u Roudnice (okr. Hradec Králové); 22 - Staré Ždánice (okr. Pardubice); 23 - Chvaletice (okr. Pardubice); 24 - Býšt' (okr. Pardubice); 25 - Břehy (okr. Pardubice); 26 - Kojice (okr. Pardubice); 27 - Dolní Holetín (okr. Chrudim); 28 - Chlumětín (okr. Chrudim); 29 - Chrudim-Podhůra (okr. Chrudim); 30 - Licomělice (okr. Chrudim); 31 - Neděliště (okr. Pardubice); 32 - Licoměřice (okr. Chrudim); 33 - Slatiňany (okr. Chrudim); 34 - Samařov (okr. Chrudim); 35 - Zádolí (okr. Ústí nad 
Orlicí); 36 - Chlumec nad Cidlinou (okr. Hradec Králové); 37 - Voleč (okr. Pardubice); 38 - Městec (okr. Chrudim); 39 Vysoké Mýto (okr. Ústí n. Orlicí); 40 - Pardubice; 41 - Hradec Králové; 42 - Čáslav (okr. Kutná Hora).

Abb. 1. Im Text erwähnte archäologische Fundstellen. Dreiecke kennzeichnen Städte und Kleinstädte, Kreise Dorfwüstungen und Sternchen Depots. 1 - Chrudim (Bezirk Chrudim); 2 - Přelouč (Bezirk Pardubice); 3 - Ronov nad Doubravou (Bezirk Chrudim); 4 - Heřmanův Městec (Bezirk Chrudim); 5 - Luže (Bezirk Chrudim); 6 - Skuteč (Bezirk Chrudim); 7 - Mittelalterliche Dorfwüstung Bolešov (Katastergebiet Spačice, Bezirk Chrudim); 8 - Mittelalterliche Dorfwüstung Drbohlavy (Katastergebiet Bošov, Bezirk Chrudim); 9 - Mittelalterliche Dorfwüstung Hody (Katastergebiet Vyžice, Bezirk Chrudim); 10 - Lipina (Bezirk Chrudim); 11 - Mittelalterliche Dorfwüstung Luhy (Katastergebiet Březinka bei Hošt’alovice, Bezirk Chrudim); 12 - Mittelalterliche Dorfwüstung Máslovanky (Katastergebiet Horní Bradlo?, Bezirk Chrudim); 13 - Befestigung, Hof und Mittelalterliche Dorfwüstung Mrdice (Katastergebiet Heřmanův Městec, Bezirk Chrudim); 14 - Svatý Mikuláš (Bezirk Chrudim); 15 - Mittelalterliche Dorfwüstung Stusyně (Katastergebiet Ronov nad Doubravou, Bezirk Chrudim); 16 - Mittelalterliche Dorfwüstung Protivany (Katastergebiet Ronov nad Doubravou, Bezirk Chrudim); 17 - Befestigung, Hof und Mittelalterliche Dorfwüstung Suchotlesky (Katastergebiet Ronov nad Doubravou, Bezirk Chrudim); 18 - Mittelalterliche Dorfwüstung Třtí (Katastergebiet Vejvanovice?, Bezirk Chrudim); 19 - Mittelalterliche Dorfwüstung Záhuby (Katastergebiet Jetonice?, Bezirk Chrudim); 20 - Mittelalterliche Dorfwüstung Zlatník (Katastergebiet Hrbokov, Bezirk Chrudim); 21 - unbekanntes Dorf oder Hof bei Roudnice (Bezirk Hradec Králové); 22 - Staré Ždánice (Bezirk Pardubice); 23 - Chvaletice (Bezirk Pardubice); 24 - Býšt' (Bezirk Pardubice); 25 - Břehy (Bezirk Pardubice); 26 - Kojice (Bezirk Pardubice); 27 - Dolní Holetín (Bezirk Chrudim); 28 - Chlumětín (Bezirk Chrudim); 29 - Chrudim-Podhůra (Bezirk Chrudim); 30 - Licomělice (Bezirk Chrudim); 31 - Neděliště (Bezirk Pardubice); 32 - Licoměřice (Bezirk Chrudim); 33 - Slatiňany (Bezirk Chrudim); 34 - Samařov (Bezirk Chrudim); 35 - Zádolí (Bezirk Ústí nad Orlicí); 36 - Chlumec nad Cidlinou (Bezirk Hradec Králové); 37 - Voleč (Bezirk Pardubice); 38 - Městec (Bezirk Chrudim); 39 Vysoké Mýto (Bezirk Ústí n. Orlicí); 40 - Pardubice; 41 - Hradec Králové; 42 - Čáslav (Bezirk Kutná Hora).

k Českému masivu, provincii Česká vysočina. Jihozápadní a jižní část území připadá do českomoravské soustavy a podsoustavy Českomoravská vrchovina, která je v regionu reprezentována geomorfologickými celky Železných hor a Hornosvrateckou vrchovinou. Na západě zasahuje na Chrudimsko malou plochou Hornosázavská pahorkatina. Podnebí je v severní části okresu poměrně teplé a suché, v jižní části je výrazně chladnější a vlhčí (základní přehled viz Faltysová-Bárta et al. 2002, 72-76).

\section{Metoda výzkumu}

Při výzkumu antropogenních reliktů na neohrožených lokalitách využíváme především nedestruktivní archeologické metody pro studium změn v struktuře osídlení v raném novověku vlivem třicetileté války (Novák-Vařeka 2016; Symonds-Vařeka 2016; Vařeka 2010; 2014; 2016). Největší penzum těchto dat a informací získáváme v převážně zalesněném prostředí Železných hor. Při nedestruktivním výzkumu archeologických lokalit využíváme zejména srovnání výstupů leteckého laserového skenování (dále LLS) a vizuálního nedestruktivního archeologického průzkumu s následným detailním geodetickým zaměřením vybraných antropogenních reliktů pomocí totální měřičské stanice LEICA TS06plus 5" R500 přímo autory příspěvku. Pro sledované oblasti Chrudimska využíváme digitální modely reliéfu 5. generace (dále DMR5G) vytvořené metodou LLS (poskytuje Český úřad zeměměřický a katastrální). Kvalita zachycených, již interpretovaných archeologických reliktů na DMR5G není zcela vyhovující, ale větší rozměry jednotlivých antropogenních a př́rodních reliktů je umožňují vcelku snadno lokalizovat, identifikovat a vizualizovat (např. úvozové cesty, hráze, montánní útvary, polní opevnění atd.). Na zemědělsky obdělávaných plochách jsou dále prováděny povrchové sběry, za určitých okolností doplněné o preventivní průzkum pomocí detektoru kovů kombinovaný s geofyzikálním měřním. V př́ípadě detektorové prospekce spolupracujeme s profesionálními institucemi (zejm. Regionální muzeum ve Vysokém Mýtě, Východočeské muzeum v Pardubicích či Muzeum východních Čech v Hradci Králové) i s amatérskými skupinami (např. Hledači historie Pardubicko, z. s.) a s jednotlivci. Všechny nálezy jsou zaměřovány pomocí GPS a při průzkumu za pomoci detektoru kovů a následné mikrosondáži jsou vždy archeologické situace zdokumentovány a zaměřeny pomocí totální stanice (srov. Vích 2015, 152-172). V neposlední řadě jsou predikce archeologických lokalit doplňovány o studium toponym v daném regionu (pro zaniklé vsi např. trati V Hodech, Zlatník; opevněné polohy - Švédské šance apod.). Zejména kombinace studia 
místních a pomístních jmen s archeologickými metodami je velmi účinná a může napovědět mnohé o kontinuitě osídlení v daném regionu.

Pokud se chceme dozvědět více o průběhu třicetileté války ve městech, městečkách a žijících vesnicích, jsme bohužel odkázáni povětšinou pouze na poznatky získané archeologickými výzkumy záchrannými, tedy takovými, které nejsou podníceny odborným zájmem, ale spíše vynuceny okolnostmi vyplývajícími z momentálních stavebních záměrů (např. Chrudim, Heřmanův Městec). Výzkumy ve městech probíhají převážně na zastavěných plochách, tedy v opakovaně narušovaném terénu. Intenzivní dlouhodobé osídlení městského prostředí vede ke vzniku stratigrafických situací, které svou složitostí kladou vysoké nároky na dokumentaci a následné vyhodnocení.

\section{Historický rámec}

Obyvatelé Chrudimska se do bojů třicetileté války zapojili již v roce 1619 . Ve většině případů šlo o představitele šlechty, kteří se začlenili do vojska českých stavů. Přímo v Chrudimi byli vojáci verbováni v srpnu až září roku 1620. Po porážce českých stavů se v Chrudimi střídala vojska všech bojujících stran. Ještě roku 1620 protáhly městem směrem na Moravu sbory generála Buquoye, poté v polovině listopadu polští vojáci pod velením Batyckého, následoval sbor Rudolfa z Tiefenbachu. Posléze se v Chrudimi načas utábořil sbor knížete saského, vedený setníkem Janem Verderem, který město vydíral a dožadoval se dalších platů pod pohrůžkou uvěznění městské rady. Na jaře roku 1622 protáhly Chrudimskem sbory Albrechta z Valdštejna, v březnu téhož roku byla v Chrudimi a v okolí ubytována jednotka kyrysarů vedená Alexandrem Haugvicem. V dubnu roku 1626 byla v Chrudimi přítomna jízdní kompanie Torquato a prapor pěchoty Breunerovy. Za zmínku stojí i jednotka Rombalda hrabě Collalta složená z benátských žoldnéřŭ, která je zde připomínána roku 1627. O rok později je v Chrudimi připomínán jízdní pluk Petra Ferrari. Ve 30. letech 17. století zde krátce sídlil generál Trotz i se svým štábem. Roku 1631 byl ve městě detašován také císařský prapor pěchoty pod vedením Adama Trčky z Lípy, po vpádu Švédů v témže roce zde byla usídlena část saského kontingentu. Těžkým břemenem pro město Chrudim bylo působení pluku Wildperka v období od 3. ledna do 13. června roku 1635.

Důležitou epizodou válečného konfliktu byl rok 1639, kdy prorazila švédská vojska pod vedením Johana Banéra do Čech. Již v květnu bylo hlášeno, že švédské partaje obsazují panství v severních a východních Čechách, přičemž se některá šlechta uchýlila do královských měst (Líva 1954, 282). V záríi již stály švédské regimenty na pravém břehu řeky Labe u Pardubic. Před blížící se zimou bylo Chrudimsko napadeno silnými partajemi (Líva 1954, 356). Šestnáctého listopadu hlásil primas města Daniel Šebestián, že Švédové vysekali bránu a s 2000 muži vnikli do města. Vyplenili některé domy a požadovali 6000 ř́šských tolarů. Sebrali 700 tolarů. Sedmnáctého listopadu předvečerem odjeli a vzali s sebou čtyři měštany jako rukojmí (Líva 1954, 363). Švédský generál tak posunul hranici obsazeného území na celý tok řeky Labe a zř́ídil tzv. Labskou pevnost, kterou se co nejdéle snažil udržet nepoškozenou, aby mu zůstala funkční vojenská a hospodářská základna pro zimní měsíce, naopak v ostatních částech země praktikoval takřka taktiku „,spálené země“, přičemž vysloveně psal v listu: „(...) Zaměřím svou pozornost na to, aby také zde nepřiteli nezbyla než studená kuchyně, a tím mu vezmu možnost se tu u mě zásobovat (...).“ (RAOSB 1893, 698). Následujícího roku švédská vojska obsadila většinu velkých měst v oblasti, 1. února poddanské město se zámkem Chlumec nad Cidlinou a 2. února dobyla Hradec Králové.

Během roku 1640 byla švédská vojska opět z Čech vytlačena a na Chrudimsko byly znovu dislokovány císařské jednotky. V únoru roku 1642 zde epizodicky pobývala císařská posádka pod velením kapitána dona Camilla Conzaga, který v Chrudimi onemocněl a zemřel. Kapitán nebyl katolíkem a jeho pobočníci pod hrozbou násilí jeho ostatky nechali pohřbít v katolickém kostele. Švédské vpády však neustávaly.

V roce 1643 vpadla do východních Čech vojska Lennarta Torstenssona. Vypleněn byl Kolín a: „Tu se pak ke Chrudimi uchýlil, aby tam podobné ohavnosti páchal a odtud na Moravu 
se odebral." Stejný scénář se opakoval v roce 1645. Východními Čechami protáhla na Moravu další švédská armáda. Lennart Torstensson „,11 dni v Chrudimi zle rádil, v kostelích oltáře rozbil a kde co ještě bylo, opět odvezl“" (Svoboda 1880, 21). Jeho vojsko se pak pustilo do obléhání Brna. Ve východních Čechách se zatím šíriily zprávy, že pokud bude Brno dobyto, přikročí Švédové k dobývání Pardubic (Líva 1955, 344).

Další vpád švédských oddílů proběhl v roce 1648, kdy nepřátelské armády vtrhly severozápadním směrem na Prahu. V září bylo z okolí Pardubic hlášeno, že se v kraji nachází množství vojáků, kteří loupí a vymáhají velké kontribuce (Líva 1957, 265). Vzápětí Švédové potřetí dobyli Chrudim. Za jejich řádění vznikl tzv. Salvátorský zázrak, kdy na obraze sv. Salvátora hráli švédští žoldnéři kostky (Klaus et al. 1926, 196-223; nejnovější zpracování událostí - Prokešová 2007; Pithart 2010; Novotná 2013). V listopadu se konečně krajem roznesla zvěst, že byl v Münsteru uzavřen mír (Líva 1957, 272).

\section{Př́ítomnost vojenských kontingentů na základě hmotných pramenů}

Prvořadým dokladem o pobytu vojenských kontingentů na Chrudimsku a v blízkém okolí za třicetileté války je pestrý soubor oděvních spínadel, která sloužila k uzavírání a dekoraci vojenských kostýmů (srov. Preusz 2017, 170-186). Zejména v souvislosti s užíváním detektoru kovů a s narůstajícím zájmem o novověkou hmotnou kulturu v posledních letech evidujeme dnes více než 150 kusů (např. Musil 2013). Detailní katalog těchto spínadel překračuje rámec předložené studie a bude publikován samostatně. Doposud z prostoru Chrudimska a Pardubicka známe dva hlavní typy - spínadla v podobě korunovaného dvouhlavého orla s hadem (obr. 2) a $\mathrm{v}$ podobě korunovaného lva $\mathrm{s}$ hadem $\mathrm{v}$ tlapách (obr. 3). Oba motivy lze vnímat jako média dobové propagandy, která úzce souvisí s ideologickým rámcem válečného konfliktu (Bossen 2006). Užití symbolů vyplývá z evangelicko-katolického antagonismu, v němž se mísila eschatologie s politickou aktualizací.

Symbolika obou motivů je primárně odvozena ze 4. knihy Ezdrášovy, která pro svůj eschatologický obsah byla oblíbená ve středověku i raném novověku, mezi apokryfní spisy ji zařadil

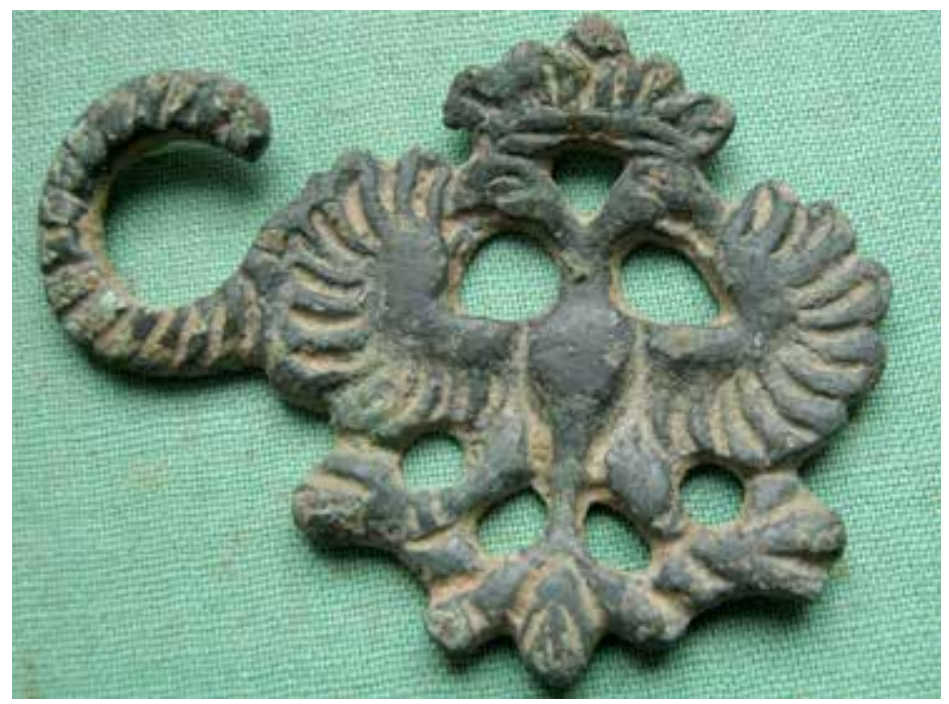

Obr. 2. Heřmanův Městec. Spínadlo v podobě korunovaného dvouhlavého heraldického orla s hadem. Foto J. Kočí.

Abb. 2. Heřmanův Městec. Kleidungsverschluss in Form eines gekrönten, doppelköpfigen heraldischen Adlers mit Schlange. Foto J. Kočí. 

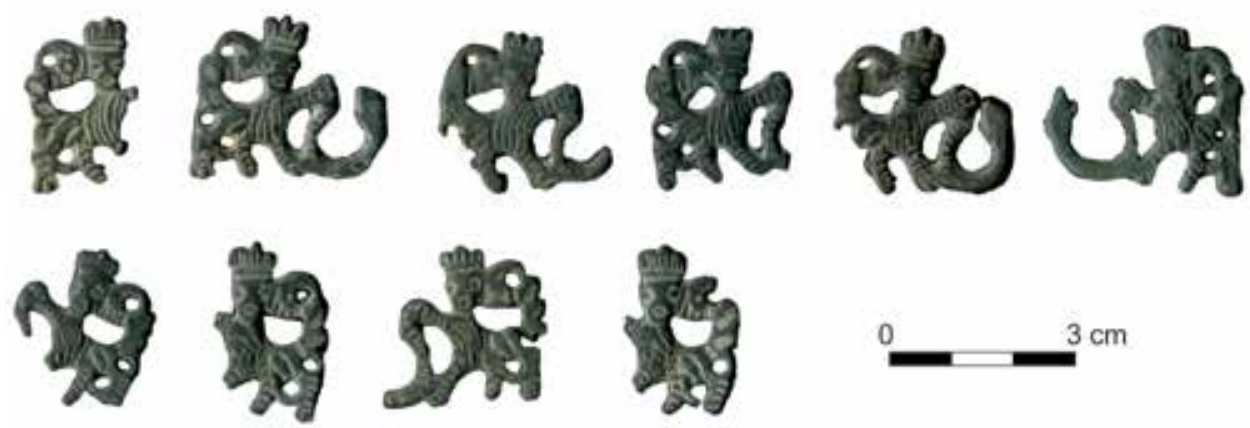

Obr. 3. Heřmanův Městec. Spínadla v podobě korunovaného lva s hadem. Foto J. Musil.

Abb. 3. Heřmanův Městec. Kleidungsverschlüsse in Form eines gekrönten Löwen mit Schlange. Foto J. Musil.

až tridentský koncil (1545-1563). Ústředním motivem Ezdrášových vidění byla otázka lidského utrpení v souvislosti s božským plánem dějin. Objevil se zde obraz, kdy Ezdráš vidí z moře vystupovat orla s dvanácti křídly, který tyransky ovládá zemi. Př́ítrž orlovu tyranství učiní rozzuřený lev z lesa, který orla úplně zničí. Smyslem tohoto boje je záchrana lidu z bídy a jeho ochrana. V další fázi vidění je zjeven proroku Ezdrášovi př́ichod a vítězství „Syna člověka“.

První typ oděvních spínadel (obr. 2) umně propojuje motiv tyranského orla s heraldickým symbolem císaře Ferdinanda III. Habsburského nebo znakem Svaté říše římské národa německého. V popředí zpodobňuje dvouhlavého orla, který má na hlavách posazenu korunu. Zpoza křídel navíc vychází hadí ocas. Ten otáčí celé prvotní významové sdělení od heraldické symboliky ke hříchu. Ztotožňuje orla s hadem. S bytostí, která v ráji svedla Adama a Evu k prvotnímu hříchu. Apokalyptické divoké zvíře mající tělo orla i hada je v konečném důsledku zosobnění Antikrista, který je tyranem zneuživajícím svou moc.

Na tento obraz navazuje motiv boje lva s hadem (obr. 3), který v sobě mísí nejen znovuzrozený antický obraz neporazitelného bojovníka Herakla ve vítězném boji s lárnéskou hydrou, ale i křest’anský motiv Bohem pověřeného řvoucího lva v boji s římskou bestií, která je zastoupena orlem, hadem, hydrou nebo drakem. Výsledkem je očekávané osvobození „dítek božích“ z tyranství apokalyptické šelmy, z papežského jha a vlády Habsburků (Urbánek 2008, 221-229).

Tento symbolický program za svůj přijal zejména švédský král Gustav II. Adolf, který $\mathrm{v}$ roce 1630 vstoupil do války proti císaři s úmyslem zasadit katolickému tyranství rozhodující úder. Své válečné úmysly programově navázal na již osvědčený ideologický podtext, jejž užil ve válce s Polskem. Tehdy sám sebe i celé švédské království stylizoval do obrazu lva od půlnoci. Motiv řvoucího lva užil v symbolické výzdobě na vnitřních stranách střílen a ohromného lva ve skoku na přídi vlajkové lodi Vasa (Hocker 2012, 74). V boji s císařem se obraz lva stal opět pilířem propagandy, avšak získal ještě navíc eschatologický rozměr v obraze nesmiřitelného boje lva ze severu s hadem. Tímto způsobem švédský král veřejně deklaroval duchovní rozměr nového vojenského tažení a po vylodění v severním Německu to doložil i ražbou pamětní medaile. Na jejím líci nechal zpodobnit svůj portrét, na rubu se prezentoval jako lev s biblí a mečem, přičemž opis na rubové straně rozhodně hlásal:

Von mitternacht kom ich daher,

Od půlnoci já mírím sem, Zu streiten ist mein Gantz Beger, Will allzeit halten Guthe Wacht, A boje žádostiv jen jsem, Gottes Auge nim mich in acht. Já stále na stráži chci být, A Bůh nade mnou bude bdit. 


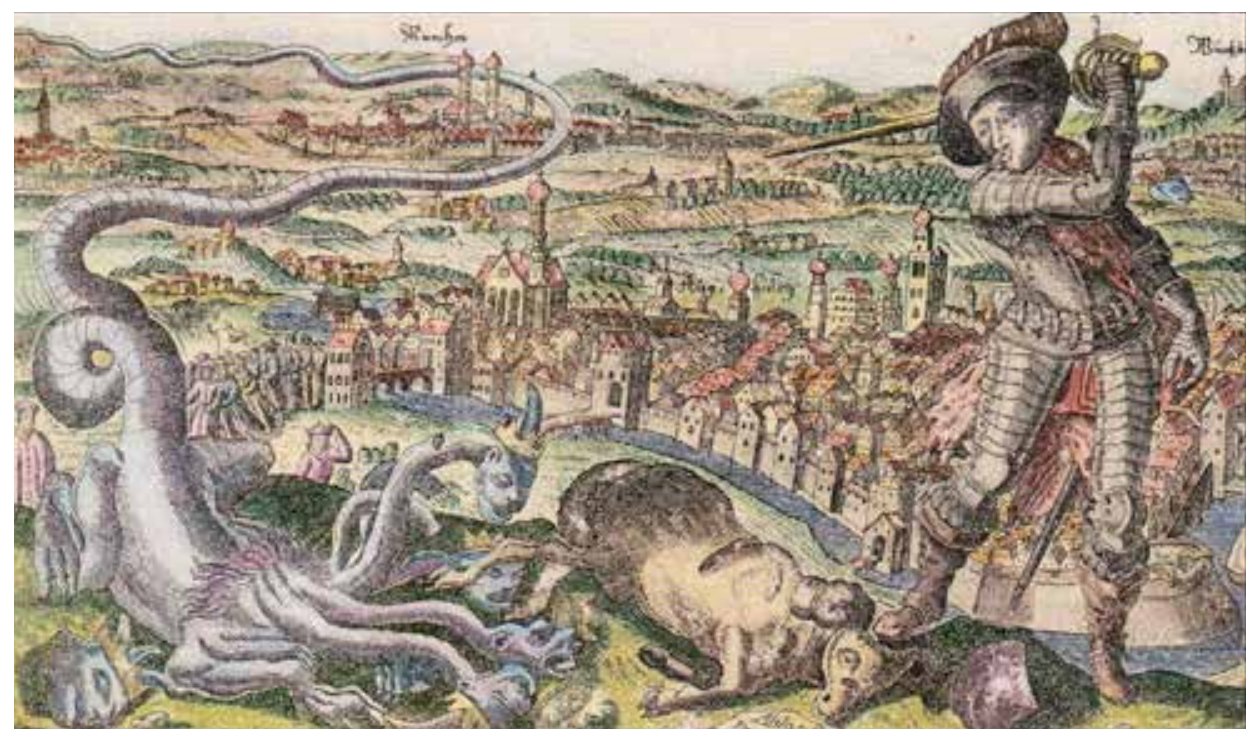

Obr. 4. Výřez obrázku z letáku k dobytí Augsburgu králem Gustavem II. Adolfem. Anonymní autor, vytištěno v Augsburgu v 2. polovině 17. století. Zdroj http://www.pahor.de/augsburg-im-30-jahrigen-krieg-bildausschnitt-nach-einem-flugblatt-nach-der-einnahme-augsburgs-durch-konig-gustav-ii-adolf-von-schweden.html, cit. 2. 6. 2016.

Abb. 4. Bildausschnitt aus einem Flugblatt zur Einnahme Augsburgs durch König Gustav II. Adolf. Anonymer Autor, gedruckt in Augsburg in der zweiten Hälfte des 17. Jhdts. Quelle http://www.pahor.de/augsburg-im-30-jahrigen-kriegbildausschnitt-nach-einem-flugblatt-nach-der-einnahme-augsburgs-durch-konig-gustav-ii-adolf-von-schweden.html, cit. 2. 6. 2016 .

Tato cílená švédská politická propaganda byla skvěle připravena. Svědčí o tom celá řada pseudo-paracelsovských proroctví, kterých bylo jen na německém území vytištěno nejméně dvacet. Dokladem jsou letáky k tažení švédského krále tzv. farskou uličkou, což byla nedotknutelná biskupská a arcibiskupská území podél řeky Rýn. Slavnostní vjezd do Augsburgu se dokonce stal symbolem utlačovaného německého protestantismu, a dobytí Mnichova patřilo jistě k největším válečným i duchovním triumfům švédského krále. Leták k dobytí Augsburgu v roce 1632 znázorňuje tentokrát švédského krále jako starozákonního hrdinu, který seká mečem hlavy císařské hydře (obr. 4). Svou naději vkládal do tažení švédského krále také nejznámější český exulant Jan Ámos Komenský, který očekával rozhodné vítězství protestantů, jež by přispělo k obnově české společnosti rozvrácené po bitvě na Bílé hoře v roce 1620 . V letech 1631 a 1632 , kdy si švédská vojska razila cestu na jih, doprovodil tažení spisem Polnice milostivého léta pro národ český, v němž i on probudil eschatologický obraz, v němž „Hospodin vzbudi od půlnoci toho [myšlen Gustav II. Adolf], kterýž oboří se na knižata jako na bláto, a pošlapá je jako hrnčír hlínu" (Chráska 1945, 7).

Je jasné, že úcta ke švédskému králi v té době již u protestantů hraničila s kultem osobnosti. Emotivní prezentace švédského krále jako lva ze severu byla již na počátku 30. let 17. století šířena skrze oděvní spínadla na vojenských oděvech vojska i skrze další artefakty. Svědčí o tom nález figurky lva s glóbem (Schürger 2015, 314, obr. 23) a nález lví hlavy, která v tlamě svírá hada, na bojišti u Lützenu (bitva zde proběhla 16. listopadu 1632). Ta byla dokonce interpretována jako pravděpodobný doplněk oděvu osobního královského gardisty, který v bitvě padl spolu se švédským králem. Kult rozzuřeného lva od půlnoci se však i po smrti Gustava II. Adolfa šíriil ve švédském vojsku dál, a to i přes absenci konkrétní vůdčí osobnosti. ${ }^{1}$ Přímým důkazem jsou nálezy spínadel korunovaných lvů s hadem v tlapách v masovém hrobě na bojišti u Wittstocku

1 Viz http://www.archaeologie-online.de/magazin/nachrichten/archaeologen-auf-den-spuren-des-dreissigjaehrigen-krieges-15577/, cit. 8. 10. 2017. 


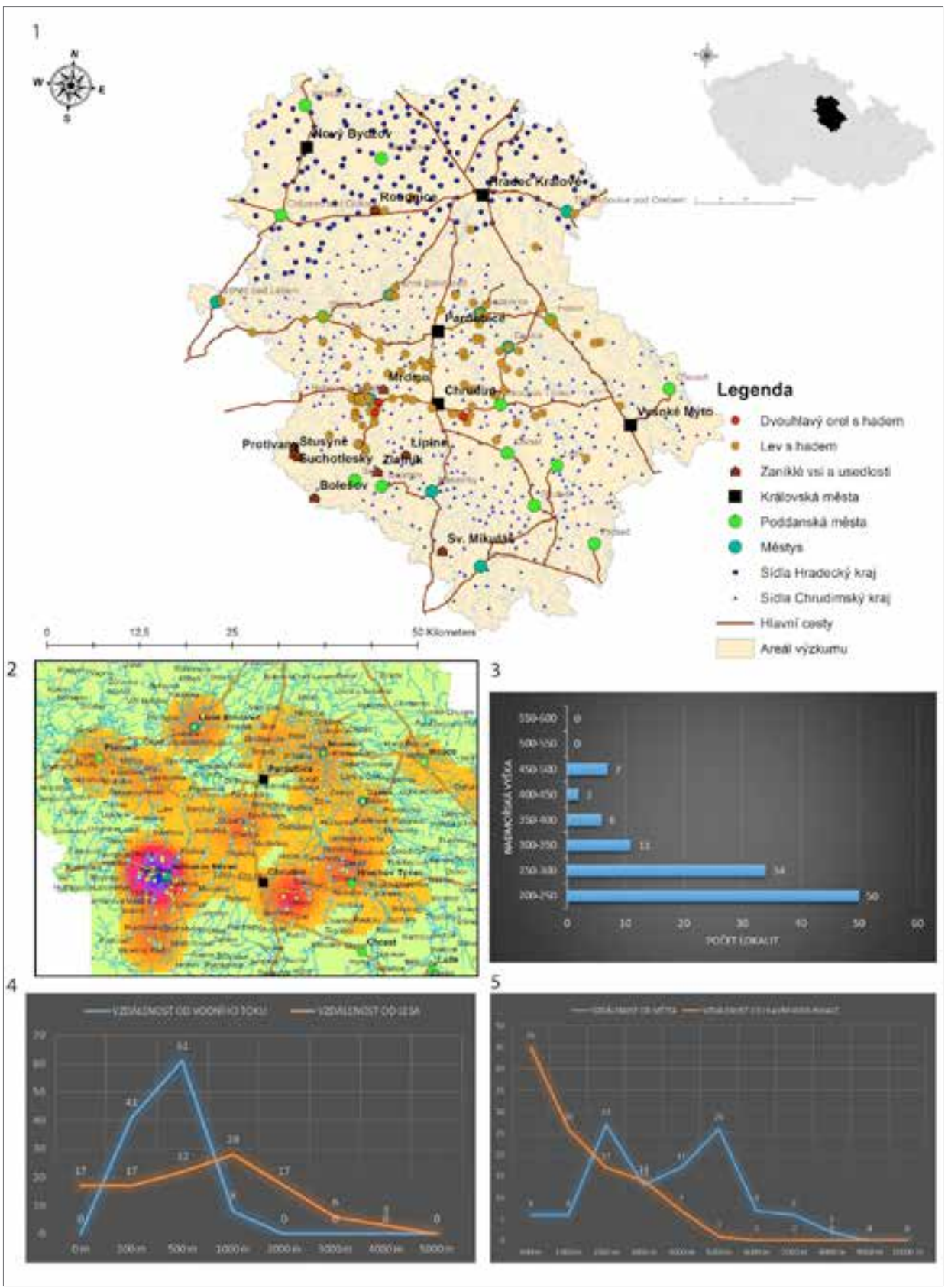

Obr. 5. Analýza strategické krajiny v krajích Chrudim a Hradec Králové na základě nálezů vojenských oděvních spínadel. Vyhotovil M. Preusz.

Abb. 5. Analyse der strategischen Landschaften in den Bezirken Chrudim und Hradec Králové anhand der Funde von militärischen Kleidungsverschlüssen. Erstellt von M. Preusz. 
z roku 1636 (Eickhoff-Grothe-Jungklaus 2012, 175) a další, dokonce stř́íbrné, analogie jsou známé i z depotu z Beeskowa v Brandenbursku, jenž byl uložen ve 30. letech 17. století (Eickhoff-Grothe-Jungklaus 2012, 38).

Vojenské nášivky s motivem korunovaného lva s hadem, které byly objeveny na Chrudimsku, Pardubicku a Královéhradecku (obr. 5), vykazují několik morfologických variant (srov. obr. 3). V řešení hlavy rozlišujeme lvy s mordou otočenou k divákovi a lvy s hlavou z profilu. Morda otočená k divákovi je zpravidla doplněna o stylizované oči a tlamu, která je bud' oválná či naznačena vodorovnou rýhou. U lvů s hlavou z profilu jsou charakteristické nadočnicové oblouky, vyplazený jazyk z mordy, mohutná hříva a znázornění ucha lva.

Dle pokrytí hlavy rozlišujeme lvy nekorunované a korunované. Koruny mají vždy tři vrcholy, přičemž se navzájem liší ve výšce provedení a dekoru, kdy nejvíce profilované korunky jsou zdobeny dvojicí tenkých rýh či tlustými rýhami v jednotlivých vrcholcích koruny. Naopak nejméně profilované a zároveň nejnižší korunky nebyly dále dekorovány. V této kategorii lze rozlišit až pět základních morfologických variant.

Širší spektrum tvarových modifikací pozorujeme u ocasu. Svým stočením či kombinací s hlavou, tělem či zadníma nohama slouží nejčastěji k vytvoření otvorů, jež umožňovaly uchycení nášivky k textilii. Těchto př́ikladů evidujeme sedm typů. Nejčastějším tvarem je nad zadní nohou zdvižený ocas, jehož horní konec je spojen s hlavou lva. Ochlupení je pouze stylizováno záhyby na vnější straně ocasu a evokováno rytím či vpichy. V ideálním případě je tato varianta doplněna o tři kruhové otvory k uchycení na oděv. Známé jsou však i případy, kdy jeden z otvorů chybí. Jednodušší formou je zdvižený ocas připojený k hlavě, přičemž k uchycení sloužil pouze velký otvor mezi tělem a ocasem. Další dvě morfologické varianty jsou známé z německého prostředí. První je esovité řešení ocasu, přičemž je ocas ve spodní části protažen mezi nohama lva a na konci je dokonale ozdoben charakteristickým mohutným ochlupením ocasu. V druhém prŕpadě je ocas zdvižen, ale stočen směrem od hlavy lva. Vzniká tak jeden otvor mezi ocasem a dlouhými chlupy na konci ocasu.

Pakliže přesuneme pozornost $\mathrm{k}$ hadu či očku, opět se nabízí pohled na vícero variant. Začneme-li hadem, pak rozlišujeme hady podle zakroucení těla a úhlu, který svírá hadí hlava a ocas. Zde jsou totiž hadí těla téměř stočená, až uzavřená do tvaru písmena $\mathrm{O}$, a těla otevřená do tvaru písmena U. Navzájem se hadi liší také řešením hlavy, která bud’ není vůbec naznačena, a tělo je ukončeno zahnutím, či je naopak řešena podrobněji, má otevřenou tlamu a oválnou rýhou je doplněna o oko. Vedle hadů se pak nachází navíc lví nášivky s očky, kdy je tělo hada nahrazeno jednoduchým kroužkem z drátu. Ten je bud' svírán ve lvích tlamách svisle, nebo horizontálně.

Informační potenciál nálezů stoupá, když je detailně dokumentován jejich nálezový kontext. Pro studium oděvních spínadel byla vytvořena mapa sídelní sítě bývalého Chrudimského kraje a části Královehradeckého kraje (obr. 5), která pro Chrudimsko vychází ze Soupisu poddaných podle víry z roku 1651 (Matušíková-Pazderová 2001) a pro Královehradecko z Berní ruly z roku 1654 (Čadková-Zahradníková 2011). Díky znalosti přesné prostorové distribuce spínadel, která se ztrácela na místech, kde se vojáci pohybovali, je možné se pokusit poznat vazbu jednotlivých nalezišt’ na nejrůznější prúírodní a sociální faktory (obr. 5:1). Skrz tyto vazby se pokusíme poznat strategickou krajinu, resp. taktický terén (Foard 2012, 21-26), v němž se švédská vojska pohybovala. Nejvyšší koncentrace nálezů v okolí Heřmanova Městce, Chrudimi, Hrochova Týnce, Sezemic, Lázní Bohdaneč, Dražkovic a Holic mohou indikovat soustředění větších vojenských sborů, jednotlivé nálezy pak rozmístění menších jednotek a hlídek (obr. 5:2).

První skupinu faktorů představují přírodní faktory ovlivňující výběr místa. Velký vliv měla geomorfologie, nebot' na členitosti terénu závisela bojeschopnost jednotlivých vojenských kontingentů a schopnost kontrolovat okolní krajinu. Svou roli při vojenských akcích sehrála nadmořská výška - návrší byla použivána ke kontrole širokého území a v bitvách sloužila k rozmístění dělostřelectva, $v$ rovině mohly být naopak rozmístěny formace pěchoty a jízdy (obr. 5:3). Nálezy vojenských nášivek indikují jejich vysokou koncentraci v nižších nadmořských výškách (celkem $86 \%$ ), v rozmezí 200 až $250 \mathrm{~m} \mathrm{n}$. $\mathrm{m}$. $-45 \%$, do $300 \mathrm{~m} \mathrm{n.m.}-34 \%$, do $350 \mathrm{~m} \mathrm{n.m.}-10 \%$. Ve 
vyšších nadmořských výškách jsou již nálezy ojedinělé (celkem 14\%), od 350 do 400 m n. m. $6 \%$, do $450 \mathrm{~m} \mathrm{n}$.m. $-2 \%$, do $500 \mathrm{~m} \mathrm{n}$. m. $-6 \%$.

Na zalesnění byla závislá viditelnost z pozic i bojeschopnost jízdy a pěchoty (obr. 5:4). Zatímco otevřená krajina skýtala výhody pro nasazení jezdectva, uzavřená krajina pokrytá lesy umožňovala nasazení pěchoty. Vojenské nášivky jsou nalézány jak v úplně zalesněné krajině $(16 \%)$, tak v krajině otevřené $(84 \%)$. Většina nášivek se však nachází do 1 kilometru od hranic lesů $(77 \%)$, přičemž s rostoucí vzdáleností od lesa ubývá nálezů $(23 \%)$.

Nutným předpokladem pro fungování armád byl neustálý př́sun pitné vody. Většinu míst nálezů evidujeme do vzdálenosti 200 metrů (34\%) či 500 metrů (56\%) od vodního toku, at' už šlo o potůček, říčku či velkou řeku (celkem $90 \%$ ). Málokdy se vojenské oddíly vydávaly dál než 1 kilometr od vodního zdroje (celkem $10 \%$ ). Mimoto však byly k napájení vojáků využívány i jiné zdroje pitné vody, zejména studny a cisterny zahloubené nejen ve městech, na vsích a hradech, ale i v polních vojenských leženích. Jedinou velkou řekou, po níž mohl být transportován proviant k vojsku, bylo Labe tekoucí skrz Hradec Králové a Pardubice směrem západním. Pro tento strategický význam byla řeka ve 40. letech 17. století švédskými vojsky využita jako přirozená hranice vůči protivníkovi a byla zde budována tzv. Labská pevnost.

Rozhodující vliv měla také podoba lokální silniční sítě, přičemž svou roli sehrávala nejen kvantita komunikací, ale i jejich kvalita. Zvýšené počty nálezů vojenských nášivek sledujeme ve vzdálenosti do 1000 metrů od hlavních zemských cest (ca 65\%), jež spojovaly velké územní celky a lokální opevněná sídla, zejména královská a poddanská města. Zajištění kontroly komunikací hrálo klíčovou roli v celkové logistice vojska, nebot' na zajištění cest závisela obranná i útočná strategie, rychlost přesunů i otázka zásobování. Po cestách bylo možné předávat rychle zprávy a skrz kontribuce či drancování obstarávat potřebný proviant, jídlo a koně. Jelikož se vojenské nášivky vyskytují do maximální vzdálenosti 5 kilometrů od hlavních komunikací, nelze vyloučit, že z taktických důvodů byl operační rádius vojenských oddílů takový, aby bylo

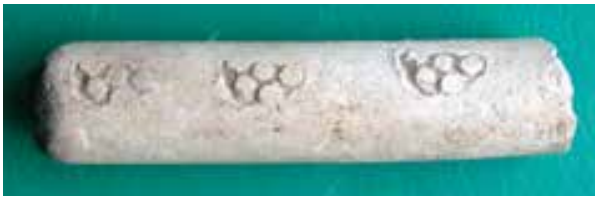

Obr. 6. Chrudim, Hradební ul. Jímka 938, k. D2/105. Troubel jednodílné dýmky se třemi rosetovými kolky, saská kopie goudských dýmek. Foto J. Frolík.

Abb. 6. Chrudim, Hradební-Gasse, Sickergrube 938, k. D2/105. Mundstück einer einteiligen Pfeife mit drei Rosettenstempeln, sächsische Kopie von Goudapfeifen. Foto J. Frolík. trend nejčastějšího výskytu oděvních doplňků ve vzdálenosti v rozmezí 1000 až 2000 metrů od sídla $(26 \%)$, které může tvořit nárazníkové pásmo. Zde mohly být soustředěny jednotky určené $\mathrm{k}$ rychlému vojenskému zásahu vůči městům. Druhý nárůst sledujeme v již bezpečné vzdálenosti 3 až 5 kilometrů ( $23 \%$ ), která dovolovala rychle doplňovat pozice u měst a zároveň mohla krýt ústupové cesty. Nálezy vojenských nášivek ve vzdálenosti 6 až 8 kilometrů jsou pak čím dál náhodnější a s největší pravděpodobností indikují př̌edsunutá postavení vojsk. Ve větší vzdálenosti pak vojenské nášivky nepozorujeme, takže i v tomto př́ípadě můžeme odhadnout, do jaké vzdálenosti se vojenské oddíly vydávaly od městských sídel.

Další skupinu artefaktů, o jejichž rozšíření se zasloužila vojska bojujících stran, představují dýmky. Největší soubor dýmek 17. století poskytují záchranné archeologické výzkumy v samotné Chrudimi. Na tomto místě je třeba zmínit publikovaný soubor z Hradební ulice obsahující 23 zlomků dýmek z 19 exempláŕů. Soubor je velmi fragmentární, z vrstev nebyl získán žádný kompletní jedinec. V souboru dominují jednodílné dýmky anglicko-holandského typu (16 exemplářů) nad dýmkami vícedílnými (6 exemplářů). Jeden zlomek se nepodařilo zařadit. Většina 


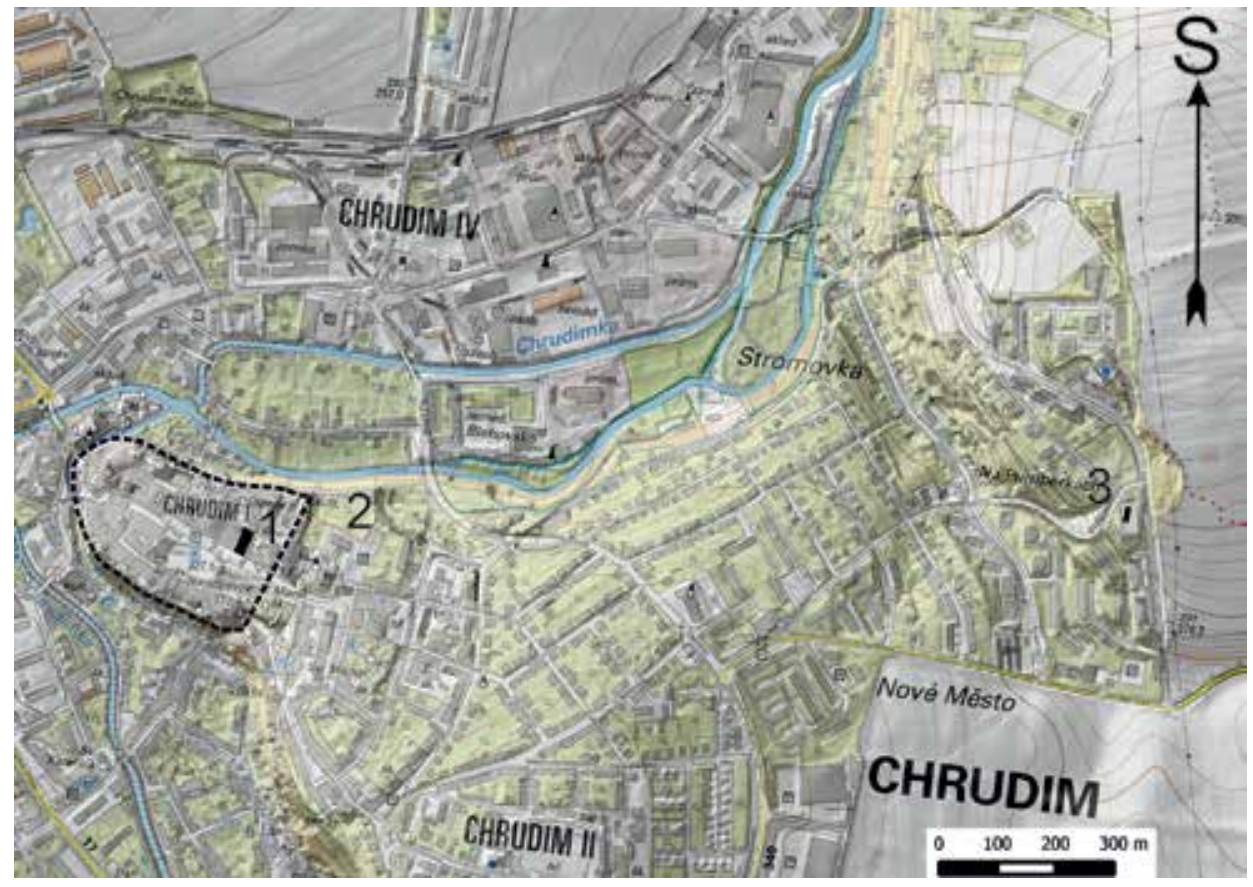

Obr. 7. Chrudim. Lokality zmíněné v textu. 1 - Hradební ul.; 2 - Klášterní zahrady; 3 - opevněná poloha Švédské šance. Vytvořeno v programu QGIS. Podklad Základní mapa ČR $1: 10000$ a DMR 4G. Zdroj ČÚZK.

Abb. 7. Chrudim. Im Text erwähnte Fundstellen. 1 - Hradební-Gasse; 2 - Klostergärten; 3 - befestigte Lage der Schwedischen Schanze. Erstellt mit der Software QGIS. Vorlage Grundkarte Tschechiens 1 : 10000 und DMR 4G. Quelle Tschechisches Amt für Landesvermessung und Kataster.

zlomků pochází z velké raně novověké odpadní jámy v severní části lokality, jakož i ze zásypu původně středověkého sklepa. Zaplnění objektů proběhlo nejpozději okolo poloviny 17. století, v souvislosti se zánikem většiny domů v tomto domovním bloku za třicetileté války. Zajímavý je výskyt časných saských kopií goudských výrobků (obr. 6 - Musil 2010, č. kat. 10 a 13). Další zlomek byl objeven v roce 2016 při rekonstrukcích teras za domem čp. 74/I v Břetislavově ulici (Musil 2016). Předobrazem pro tento rosetovitý kolek je znak goudských dýmkařů - šestilistá růže (Duco 1982; 1987; van der Meulen 1994). Kolky ve tvaru rostlinného květu se mohou objevit i na nizozemských dýmkách, jejich provedení se však poněkud liší (srov. Thier 1990, Abb. 17 a 18 - druhý kolek představuje nejen květ růže, ale i stylizovaný stonek; dýmky z Lüneburgu mají kolek na hlavičce - Articus 1990, Abb. 1 - nahoře; 1997, 4-44; shodný kolek je i na troubeli dýmky z Kanovnické ul. čp. 73 v Praze, srov. Frolík-Smetánka 1997, obr. na s. 222; stylizovaný květ růže $\mathrm{s}$ korunkou nalezneme i na goudské dýmce nalezené na hradě Lüdinghausen - Thier 1991, 4-12). Tyto kolky byly imitovány a měly dokládat kvalitu prodávaného zboží, což je jev opakující se v nejrůznějších obměnách do současnosti. Identický kolek byl použit na dýmce nalezené v Lipsku (Kluttig-Altmann-Mehler 2007, Abb. 2b). Ve druhém př́ípadě nás překvapí odlišná výrobní technologie, kterou se saští dýmkaři odlišují od svých nizozemských kolegů. Hlavička byla vytočena na kruhu a troubel $\mathrm{k}$ ní byl přidělán dodatečně (dýmky skupiny 1 Kluttig-Altmann-Mehler 2007, 72-76, Abb. 2c).

Výrazná je i skupina dýmek s hnědou a zelenou glazurou (Musil 2010, č. kat. 1 a 13), které pravděpodobně pocházejí ze Slezska (srov. nálezy z Lüneburgu a Vratislavi - Kluttig-Altmann 2005, Abb. 2). 


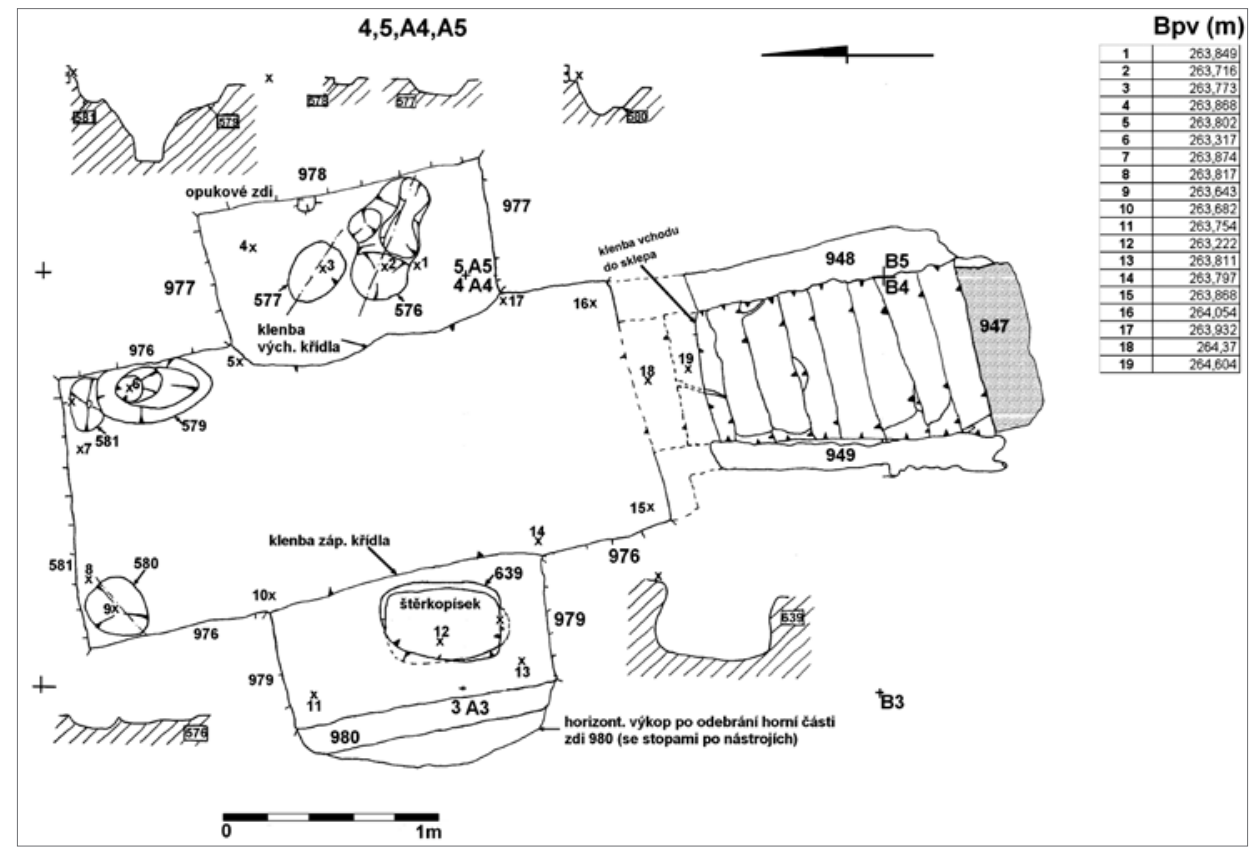

Obr. 8. Chrudim, Hradební ul. Půdorys druhého patra sklepa o křížovém půdorysu s patrnými podzemními skrýšemi. V západním výklenku je patrné odstranění části zazdívky z důvodu hledání skrýše. Kresba P. Leidemann, digitalizace J. Musil. Abb. 8. Chrudim, Hradební-Gasse, Grundriss des zweiten Kellergeschosses mit kreuzförmigem Grundriss und erkennbaren unterirdischen Verstecken. In der westlichen Nische kann man die zwecks Suche des Verstecks erfolgte Entfernung eines Teils der Einmauerung erkennen. Zeichnung P. Leidemann, Digitalisierung J. Musil.

Pokud jde o zlomky dvojdílných dýmek je zřejmé, že pochází z některé uherské dílny fungující po polovině 17. století. Uherské dílny produkovaly redukční černé i oxidační červené, jakož i fajánsové zboží (srov. dýmky z Modry - Kalesný 1981; mladší dýmky z Košolné - Holčík 1984, obr. II a III). Dekor byl prováděn bud' přímo ve formě nebo po zaformování pomocí kolků a radélka, jak je tomu v př́ípadě našeho exempláře (Musil 2010, č. kat. 3). Nejbližší analogií jsou dýmky vyráběné na Spišském hradě (srov. Vallašek 1983, obr. 7 a 8).

\section{Města}

Archeologické poznání měst na Chrudimsku obecně je s výjimkou Chrudimi teprve na počátku. Ačkoliv víme, že vojenské události třicetileté války se silnou měrou dotkly měst a městeček Přelouče (napřr. Vorel 2002, 7-44), Ronova nad Doubravou, Heřmanova Městce (Klaus et al. 1926, 381-383), Luže (Voráček et al. 2010, 89-95) a Skutče (Voráček et al. 2011, 46), chybí nám u nich příslušný archeologický obraz. V naprosté většině případů totiž narážíme na absenci větších plošných odkryvů, a pokud byly provedeny (např. Heřmanův Městec), nebyly jejich výsledky detailně publikovány. Naše poznatky o hmotné kultuře se tedy opírají zejména o Chrudim, která je systematicky archeologicky sledována od 80. let 20. století. Horizont třicetileté války se vyznačuje výrazným zásahem do života obyvatel zkoumaných parcel, který je plně ve shodě s obrazem vykresleným dobovými písemnými prameny. Zatímco v roce 1610 se v Chrudimi nalézalo 421 domů, k roku 1654 prameny evidují 152 zaniklých domů ve městě a 83 na předměstích (Dvorský 1882, 23). Obecně můžeme říci, že pro horizont první a druhé poloviny 17. století je charakteristický razantní nárůst souvrství obsahujících převážně odpad ze zaniklých domácností (srov. Musil 2016), rozsáhlé planýrky a demolice. V plochách městských parcel 


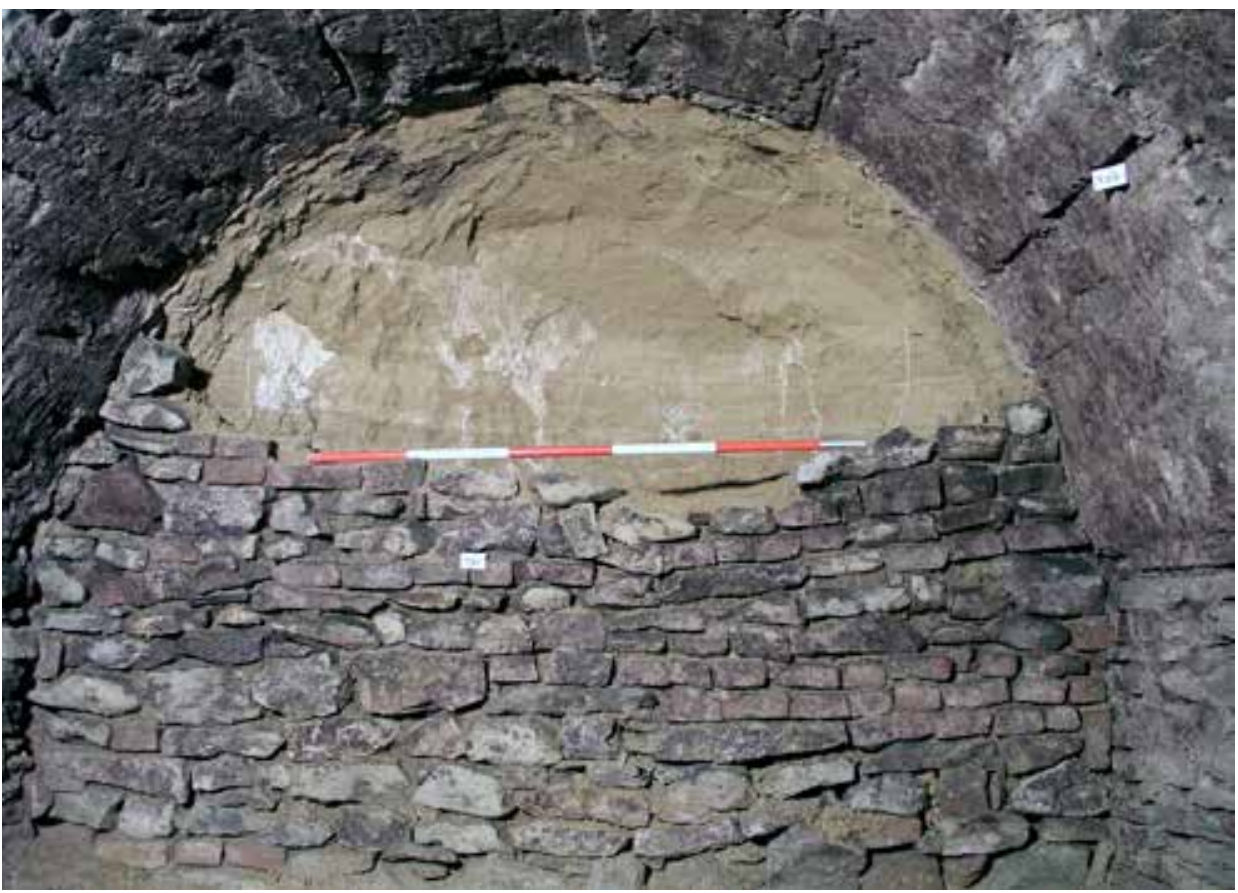

Obr. 9. Chrudim, Hradební ul. Detail odstraněné zazdívky západního výklenku druhého patra sklepa. Foto J. Frolík. Abb. 9. Chrudim, Hradební-Gasse. Detail der entfernten Einmauerung der westlichen Nische des zweiten Kellergeschosses. Foto J. Frolík.

i v ploše parkánu se setkáváme jednak s rozsáhlými souvrstvími o mocnosti 1-1,5 m, a dále se vzájemně se porušujícími odpadními jamami bez jakékoliv úpravy stěn. Tyto odpadní jámy nahradily od středověku fungující kameny roubené fekální jímky. Mimo architektonických článků se setkáváme s keramickým inventářem, mezi jehož charakteristické znaky patř́i imitace kamenin, výzdoba provedená vymačkáváním do formiček, talířové mísy malované kukačkou apod. Skleněný inventář je zastoupen zejména pohárky s polovejčitou či vřetenovitou kupou a s patkou tvořenou spirálovitě stočenou nití, džbánky a lahvemi. Další skupinu nálezů představují drobné předměty denní potřeby, často poškozené, a mince. Zcela novým fenomén představují nálezy jednodílných a dvoudílných keramických dýmek (Musil 2016).

Patrně nejvíce informací poskytl záchranný archeologický výzkum v Hradební ulici (obr. 7:1) předcházející v roce 2006 výstavbě obchodně bytového centra Balustráda na místě zaniklých domů čp. 14/I a 15/I (Frolík-Musil 2010). Archeologický výzkum v roce 2006 nevstupoval na nedotčenou plochu. Proluka pro novostavbu vznikla již v roce 1994 po zboření domů čp. 14/I a 15/I, obrácených průčelím do Resslova náměstí. Na takto vzniklé ploše měla být postavena bankovní pobočka. Plánované výstavbě předcházel v srpnu až listopadu 1994 předstihový výzkum na ploše dvorků obou zaniklých nemovitostí (Sigl 1995, 61-72). Stavební záměr se posléze nerealizoval a prozkoumaná plocha zůstala nezastavěná. Zjištěny byly složité stratigrafie pokrývající období od pravěku až do novověku a několik odpadních jímek. V těsném sousedství plochy zkoumané v roce 1994 byl v 15. století vyhlouben obdélný sklep o rozměrech cca $6 \times 4 \mathrm{~m}$, zděný na maltu a zaklenutý valenou klenbou. Přístupný byl od západu zděnou šijí se sedmi dochovanými kamennými schody a částí kamenného portálu. V době jeho funkce bylo do podlahy sklepa vyhloubeno zděné schodiště, které ústilo do druhého patra sklepa o křížovém pưdorysu. Spodní podlaží sklepů bylo hloubeno hornickým způsobem a posléze obezděno kamenem 


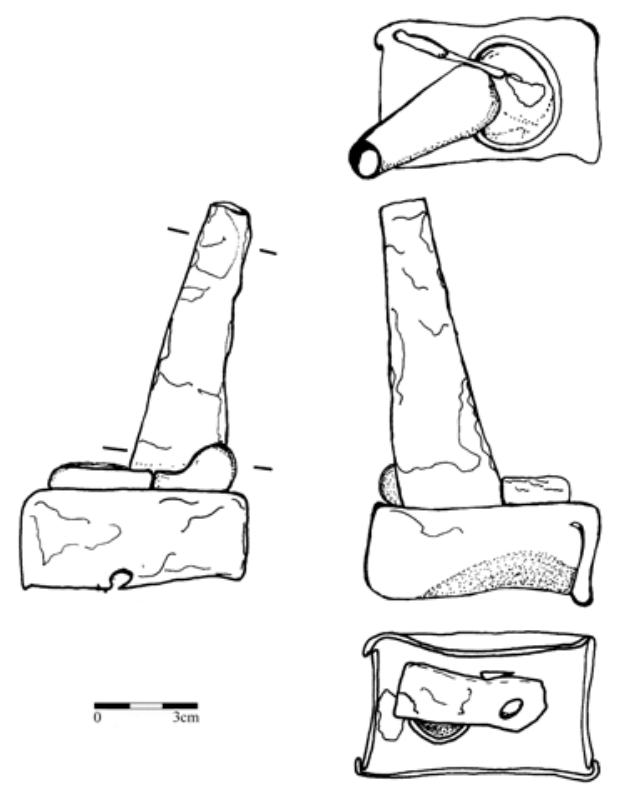

Obr. 10. Chrudim, Hradební ul. Kování prachovnice nalezené pod podlahou sklepa. Kresba J. Musil.

Abb. 10. Chrudim, Hradební-Gasse. Beschlag einer unter dem Kellerfußboden gefundenen Pulverbüchse. Zeichnung J. Musil. sklepa, a za ní stopy po neúspěšném hledání skrýše za kamennou stěnou (obr. 9). Po začištění dusané podlahy sklepa se vyrýsovala řada jam charakteru skrýší (obr. 8), přičemž v jedné z nich bylo objeveno unikátní kování prachovnice (obr. 10 - Musil 2010a).

Další fragmenty zástavby byly prozkoumány u západního okraje výzkumu, kde byly zachyceny průčelní stěny domů, stojících původně podél východní strany Hradební ulice. Objeveny byly části dvou domů (čtverec $\mathrm{C} 7$ ). $\mathrm{V}$ jednom případě se jednalo pouze o část základového zdiva (interiér domu se nacházel mimo zkoumanou plochu). $V$ druhém př́padě byla zjištěna část klenutého sklepa, vyplněná navážkami a planýrkami, datovanými do 17. století. Dům zanikl za trricetileté války a nebyl obnoven. V jeho stěně byl objeven depot pěti stříbrných mincí sestávajících z benátských (2 ks) a španělských ražeb (3 ks) z let 1622-1639 (obr. 11).

Podél východní strany Hradební ulice vznikla druhotně zástavba, jejíž průčelí ustoupilo východním směrem. Tyto domky byly demolovány v 19. století při přemistování trasy Hradební ulice. Výraznou součástí nálezového obrazu jsou odpadní jímky a jámy. Jako jímky (celkem deset) označujeme v půdorysu pravidelné jámy (kruhové či pravoúhlé) obvykle s dřevěnou úpravou stěn nebo obezděním z kamenů na sucho. Odpadní jámy (celkem čtyři) úpravu stěn postrádají. Chronologicky pokrývají období od přelomu 13. a 14. století do století osmnáctého. Zdá se, že po třicetileté válce byly na zkoumaných parcelách (tj. dvorcích domů čp. 10/I, 14/I a 15/I) hloubeny již jen odpadní jámy.

Nejvíce odpadních jímek spojujeme s parcelou domu čp. 14/I (celkem sedm jímek). Prozkoumané jímky se nacházejí v severozápadní části dvorku především podél hranice s čp. 11/I. Jímky pokrývají období do přelomu 13. a 14. století až do století 17 . K zadní části parcely domu čp. 14/I byl zřejmě druhotně připojen nevelký výběžek směrem $k$ Hradební ulici. Ten byl z valné části prozkoumán již v roce 1994 a byly zde zjištěny tři odpadní jímky z horizontu 16.-17. století (Sigl 1995, 61-72). Vzhledem k tomu, že nevíme, zda je př́islušnost tohoto výběžku k parcele čp. 14/I výsledkem vývoje pokročilého středověku nebo až novověku, nemáme jistotu, zda v období, kdy se zaplňovaly, patřily k této nemovitosti. Dvě odpadní jímky ležely na dvorku domu 


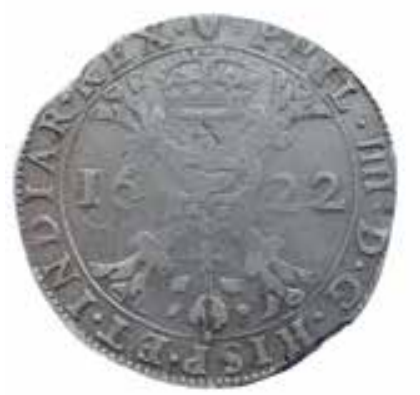

1
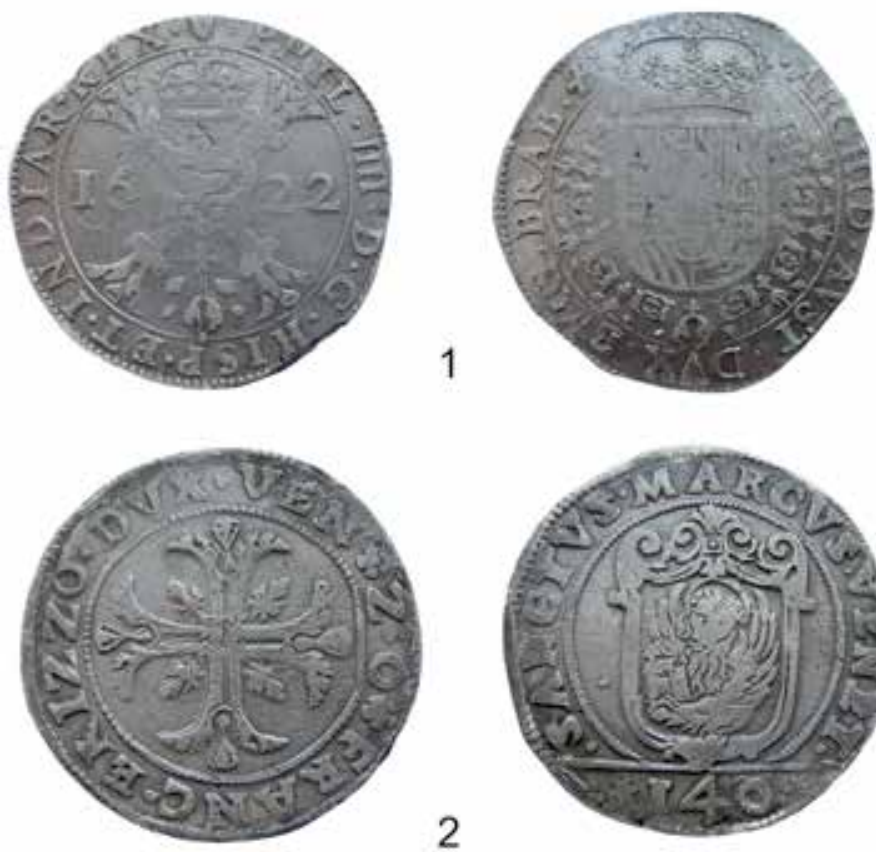

2
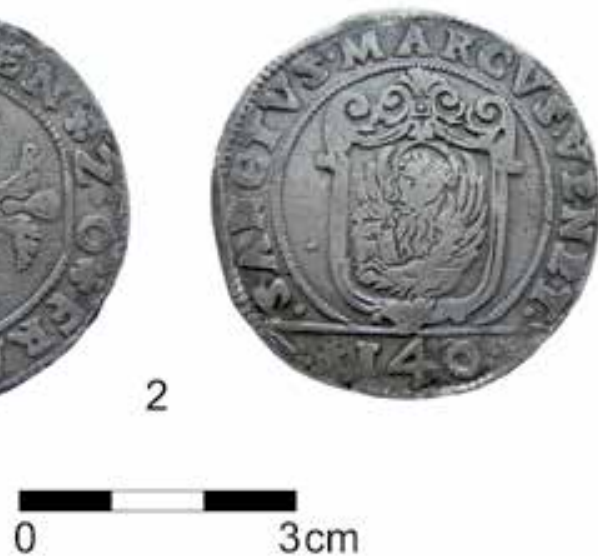

Obr. 11. Chrudim, Hradební ul. Výběr stř́íbrných mincí z depotu uloženého ve sklepě domu ve čtverci C7/140. 1 - maravedi (Filip IV.; 1621-1665), z roku 1622, španělské Nizozemí; 2 - scudo (dóže Francesco Erizzo; 1631-1646). Stř́ibro. Foto J. Frolík.

Abb. 11. Chrudim, Hradební-Gasse. Auswahl an Silbermünzen aus dem im Keller des Hauses im Planum C7/140 angelegten Depot. 1 - Maravedi (Philipp IV.; 1621-1665), aus dem Jahr 1622, Spanische Niederlande; 2 - Scudo (Doge Francesco Erizzo; 1631-1646). Silber. Foto J. Frolík.

čp. 15/I (14. a 15. století). Vzhledem k tomu, že dvorek tohoto domu byl prozkoumán v úplnosti, je zřejmé, že chybějí jímky pro následující období. $Z$ tohoto důvodu by byla vysvětlením prŕíslušnost výběžku parcely domu čp. 14/I původně k domu čp. 15/I. Jímky př́slušné k domu čp. 15/I by pokrývaly celou dobu jejich používání a disproporce $\mathrm{v}$ jejich počtu mezi dvěma sousedními dvorky by nebyla tak velká (obr. 7:5). Z období mladšího je doloženo na každém dvorku po jedné odpadní jámě.

Zbylé jímky a jámy leží na pozemku, který patřil k domu čp. 10/I. Jedná se však o přináležitost zčásti druhotnou, protože původně zde stál dům zaniklý za třicetileté války. $Z$ tohoto důvodu patř́i k domu čp. 10/I bezpečně pouze jedna jímka. Ostatní „chybějící“ jímky se mohou nacházet $\mathrm{v}$ nezkoumané části dvora. Nesporně $\mathrm{k}$ tomuto domu náleží také odpadní jáma 503 ve čtverci A5, datovaná podle nálezů do 18. století. Vyhloubena byla do planýrek zaniklého domu. Zaniklý dům vyplňoval $\mathrm{z}$ převážné části $\mathrm{k}$ němu př́íslušející pozemek. Zdá se, že volný zůstal pouze úzký pruh terénu po jeho severní straně, který mohl sloužit jako dvorek. Na něm byla vyhloubena jediná jímka 943, delší dobu po svém zániku nahrazená rozměrnou odpadní jámou 501. $\mathrm{V}$ př́ípadě této jámy nelze úplně vyloučit ani její vyhloubení až po zániku domu. K zaniklému nárožnímu domu tedy s největší pravděpodobností patřila pouze jediná jímka. Nevelký dvorek vyhloubení více jímek nejspíše nedovoloval. Z tohoto hlediska není jistě náhodou, že jímka 943 
byla ze všech zkoumaných jímek nejhlubší $(7,1 \mathrm{~m})$ a byla zřejmě opakovaně vybírána a znovu zaplňována, jak naznačuje rozbor nálezů, především skla.

$\mathrm{S}$ bohatstvím archeologických nálezů kontrastuje chudoba soudobých písemných pramenů, které by dovolovaly určit některého z vlastníků nemovitosti. Z historického hlediska byl domovní blok součástí Bohaté, dřive Klášterské čtvrti. Původní pojmenování se váže k dominikánskému klášteru, který stál severně, ale zanikl za husitských válek. Na jeho místě nadále fungovalo městské vězení.

Písemné zprávy o jednotlivých domech až do 17. století mlčí. Domovní blok tvořilo v novověku sedm nemovitostí, připočteme-li zaniklý nárožní dům, pak osm. V době výzkumu stály pouze tři domy, a to samostatná čp. 9/I a čp. 10/I. Původní čísla čp. 11/I až čp. 13/I byla sloučena v jeden celek. Historické údaje byly čerpány z topografie Čeňka Floriána (Florián s. d.).

Číslo popisné 9/I (dnes nahrazené novostavbou z 20. století) se poprvé připomíná až v roce 1709. Sousední dům, čp. 10/I, se připomíná poprvé jen o několik let dříve. V roce 1705 obec prodala místo pusté za pivovarem zemřelého Václava Píseckého Danieli Maršálkovi, ,aby dům způsobný od kamene vyzdvihnouti na témž mistě povolen byl“, za 5 kop míšeňských. Až v roce 1809 se poprvé připomíná zahrádka (tj. plocha podrobená archeologickému výzkumu v roce 2006 - „varní dům se zahrádkou“). Mladší historie je již mimo sledované téma.

Nárožní dům čp. 11/I nás zavádí svou nejstarší zmínkou přímo do událostí třicetileté války. $\mathrm{V}$ roce 1628 odkazuje Adam Bochauf z Polkenštejna veškerý majetek synu Václavovi, [jeho] manželce Marii a jeho dědicům, aby „srovnavše se [syn] s ním [otcem] v náboženství svatém katolickém a od mista neucházejic opatroval“" otce, který k němu měl důvěru, „že Danieli synu a Lidmile dceři, jakožto bratru a sestře své, kteři jeho pána Adama Bochaufa opustili, když by se zase do města tohoto Chrudimě navrátili anebo mezitím jakkoliv o to porovnati mohli, křivdy neučini". V rodině Bochaufů se dům připomíná v letech 1638 a 1671 . V roce 1680 dům odkázal Jan Josef Bochauf z Polkenštejna, chrudimský rychtář, Václavu Ivanovi Píseckému, spoluradnímu a bratru svému ,jednobřišnému“. Z přehledu zpráv vyplývá, že dům nebyl za třicetileté války zřejmě významněji poškozen. Jeho součástí byl pivovar (první zmínka 1638). V roce 1692 se připomíná „místo pusté vedle pivovaru Václava Píseckého“ jako prodané Václavu Štěpničkovi, řemesla novoševcovského, za 4 kopy. Lokalizovat tento pozemek, podle ceny nepř́liš velký, je obtížné. Před tím a ani později se nepřipomíná. Vzhledem k velikosti městiště domu čp. 11/I je možné, že by se mohlo jednat o jeho část snad někde na severní straně (k čp. 10/I?). V rodině Píseckých a jejich ženských potomků se udržel až do roku 1797. V roce 1719 se velice přesně lokalizuje jako dům s pivovarem ,vedle domu vdovy Kateřiny Kroupové [= čp. 12/I] a ulice jdoucí na starý klášter, na rohu ležíci". Do jednoho celku s nemovitostmi čp. 12/I a čp. 13/I byl sloučen $\mathrm{v}$ roce 1902.

Ještě starší zmínku nacházíme u domu čp. 12/I, který se poprvé připomíná v roce 1609 , kdy zde stojící dům prodala Lidmila, vdova po Adamovi Jeníkovském, Tobiáši Šarfenberkovi z Bindenthalu za 580 kop míšeňských. Tobiáš „Doktor“ vlastnil dům ještě v roce 1622. Během třicetileté války byl dům zřejmě zpustošen a původní majitel zemřel (nebo emigroval?), protože chrudimská obec v roce 1641 prodala dům zvaný Doktorovský vedle domu Václava Píseckého a domu Adama Kalivody manželům Kryštofovi a Aleně Blatnickým za 200 kop ,prohližejíce k nemalému spuštěni jeho a obzvláštně od ohně prudkého zruinirováni". Manželé Blatničtí pravděpodobně dům nevlastnili dlouho, protože už v roce 1661 rychtář Jan Máj dům koupený opět od obce prodal Jiřímu Chrápkovi. Později přechází dům postupně na rodiny Loutkovských a Kroupů. Byl pravděpodobně v průběhu let zvelebován, jak by mohla naznačovat postupně rostoucí cena (pokud není důsledkem inflace). Dům se nikde blíže nepopisuje kromě údaje, že je várečný. Jako samostatná nemovitost přetrval až do roku 1902.

Nemovitost čp. 13/I zaznamenáváme poprvé v roce 1641 díky lokalizaci domu sousedního. První konkrétní zmínku nacházíme k roku 1657, kdy Dorota, vdova po zemřelém Adamu Kalivodovi, prodala dům vedle domu Kryštofa Blatnického a „domu pustého slove Hodinovského“ za 210 kop Šimonu Vomáčkovi. Dům nebyl zřejmě událostmi třicetileté války poškozen. Již v roce 1668 Šimon Vomáčka prodal dům vedle domu Jiřího Chrápka a „domu pustého slove 
Formanovského z strany druhé“ za 200 kop Jiřímu Novotnému a jeho manželce Sibyle. Nižší cena naznačuje, že nemovitost nebyla zřejmě příliš udržovaná. Další změny majitelů provází rostoucí cena, nemovitost byla pravděpodobně zvelebována. V roce 1797 se v domě připomíná šenkovna. Zpráva z roku 1818 dává nahlédnout detailněji, jakou měla nemovitost podobu, protože Jan a Kateřina Strakovi si při prodeji vymínili ,ve velké světnici byt, jeden vrchni sklep, jeden horni a jeden dolni špejchárek, nahoře komoru, na dvorečku v chlévě misto pro dobytek". V roce 1902 byla nemovitost spojena s čp. 11/I a 12/I.

Dům čp. 14/I nám svými nejstaršími zmínkami (1657 a 1668) připomíná události třicetileté války. Pojmenování zpustlého městiště upomíná na jinak neznámé předchozí (?) majitele (,dưm Hodinovsky“", „dỉm Formanovsky'“). Pustá byla parcela ještě v roce 1685, kdy místo pusté vedle Augustina Paumbergra, ,jdouc $k$ vězení obecnímu v Bohaté čtvrti“", prodala městská obec za 4 kopy hotové Jindřichu Maršálkovi ,tím oumyslem, aby vyzdvihnuto a jeden kontribuent přibýti mohl“. Jindřich Maršálek dům skutečně postavil, v roce 1709 byl oceněn na 180 zlatých. Maršálkové dům drželi až do roku 1735, kdy byl prodán za 440 zlatých Václavu Brozanskému i s vnitřním vybavením. Soupis vyjmenovává mimo jiné základní potřeby pro vaření piva a lze odvodit, že v domě byla hospoda. Další osudy této nemovitosti jsou sledem výměn a prodejů při pozvolna rostoucí ceně. Její existence se uzavřela v roce 1994, kdy byla po poškození výbuchem plynu zbořena.

Nejhlouběji do minulosti sahají naše znalosti o nárožní nemovitosti čp. 15/I. V roce 1601 zde stojící dům prodal Matouš Radouš, zastupující Markétu, vdovu po Šimonovi, Slovákovi Martinovi šenkýři za 300 kop míšeňských. Šenkýř Martin již v roce 1609 dům prodal za stejnou cenu Adamu Martysovi. V roce 1613 změnil dům ,vedle domu šatlavního ležici“" majitele, byl prodán opět za 300 kop Václavu Benedicti a jeho manželce Maruši. Hned následujícího roku přešel dům prodejem při nezměněné ceně do rukou Tomáše a Anny Bobrovských, řemesla kožešnického. Druhá manželka Tomáše Bobrovského Dorota dům splácela ještě v roce 1632. Dorota se vdala za Matěje Kunata a v této pozici vystupuje v roce 1635 , kdy dům postupuje svému druhému manželovi. Při té příležitosti se uvádí, že „,mušketa a šavle při gruntu zůstati $m a ́$ '. Historie domu se načas uzavírá v roce 1637, kdy ho Matěj Kunat prodal (znovu za 300 kop) Frydrychu Trnkovi. Pak následuje v písemných zprávách dlouhá mezera, protože s další zmínkou se setkáváme až k roku 1711. Obec tehdy prodala pusté místo „Klatovské“ vedle domu Jindřicha Maršálka za 10 kop Janu Krejčímu, ,aby budoucně dům pořádný ne ode dřeva nýbrž od kamene tu vyzdvižen byl“. Stavba byla na tři roky osvobozena od daní. Z této zprávy vyplývá, že původní nemovitost byla za třicetileté války zničena a obnovy se dočkala z celého bloku jako poslední. Cena pozemku (10 kop) je mezi obnovovanými nemovitostmi nejvyšší. Nezdá se však, že cena byla ovlivněna např́íklad jeho velikostí, protože se nemohla lišit velikostí od parcely sousední (čp. 14/I). Je možné, že v této době byla dokonce menší (pokud velikost z 19. století odpovídá velikosti z 18. století). Jan Krejčí, povoláním švec, dům opravdu postavil, ale již v roce 1721 zemřel. Obec dům ,proti domu kázně v Bohaté čtvrti prodala Františku Všetečkovi za 250 zlatých. Při dalším prodeji v roce 1727 manželům Samuelovi a Rozalii Urbanovým se dozvídáme něco o jeho vnitřním vybavení (,s jedním velkým stolem, šencktišem, mandlem, též is tou v tomto nynějším pořádku přicházejici várkou“"). Také existence tohoto domu se uzavírá zbytečnou demolicí v roce 1994.

Shrneme-li uvedené písemné zprávy a pokusíme-li se je konfrontovat se svědectvím archeologie, bude výsledek poměrně skromný. Jasná je značná devastace způsobená během třicetileté války, kdy v celém bloku zřejmě zůstaly stát pouze dva domy. Skutečnost, že zpustlá městiště prodávala obec, svědčí o tom, že původní majitelé bud' zahynuli, nebo museli Chrudim opustit. Důvodem odchodu mohla být i víra, jak naznačuje svědectví z roku 1628 týkající se domu čp. 11/I. Obnova bloku trvala poměrně dlouho (nejméně do roku 1711), přičemž archeologicky objevený nárožní dům již obnoven nebyl. Nízká cena prodávaných parcel svědčí o tom, že byly opravdu ,pusté“, tj. bez stojícího domu.

Vzhledem k tomu, že se písemně doložená historie domů víceméně míjí s archeologickým svědectvím, je konfrontace konkrétních poznatků obtížná. Nejvíce údajů o životě obyvatel 


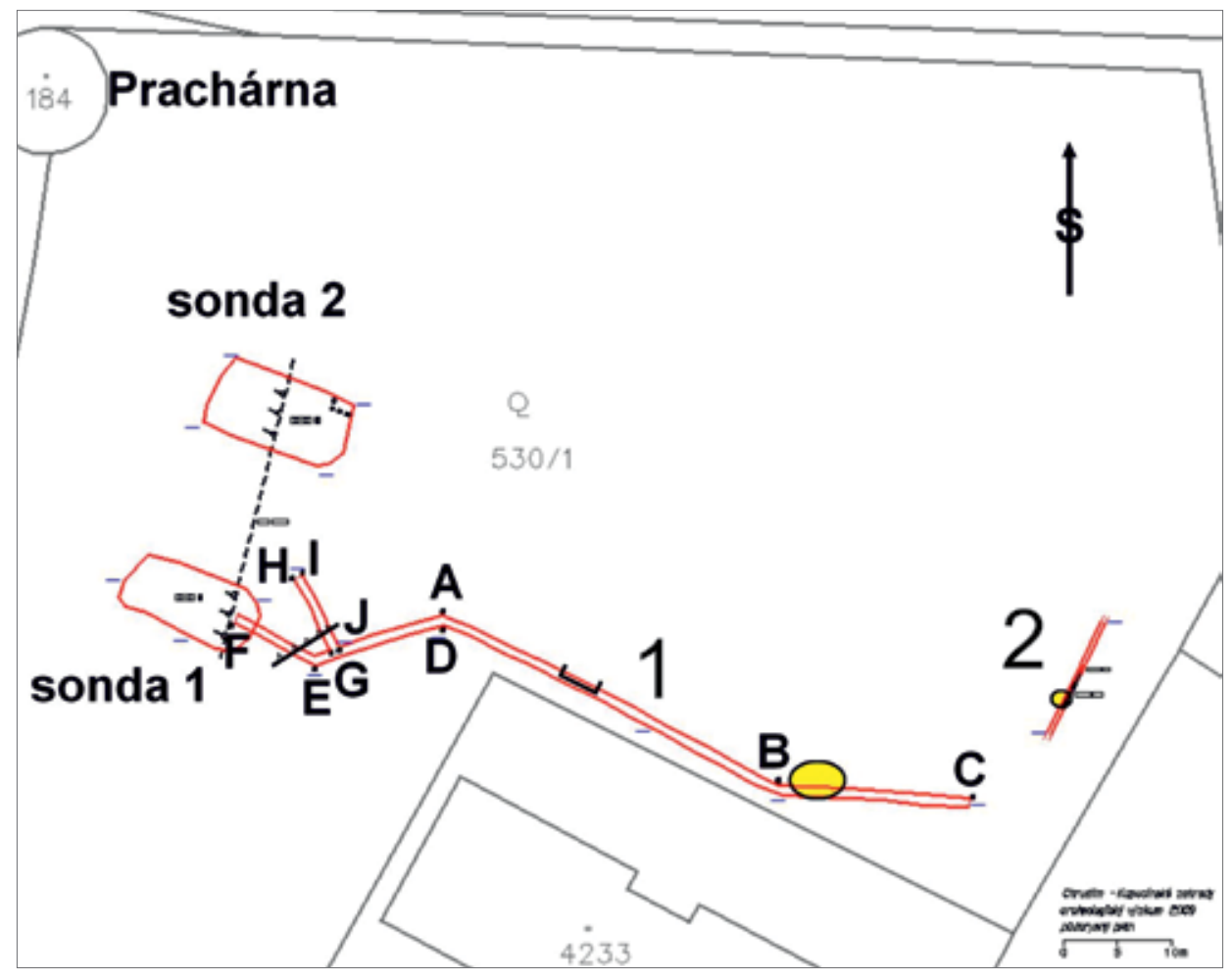

Obr. 12. Chrudim, Novoměstské předměstí, klášterní zahrady. 1 - zaniklý zděný dům s přilehlými odpadními jámami (B a C); 2 - zděná odpadní jímka. Podle zaměření firmy GEO-CZ upravil J. Musil.

Abb. 12. Chrudim, Neustädtische Vorstadt, Klostergärten. 1 - wüstes Steinhaus mit daran angrenzenden Abfallgruben (B a C); 2 - Wand einer Sickergrube. Nach einer Vermessung von fi. GEO-CZ bearbeitet von J. Musil.

přinášejí obsahy jímek, ovšem nejmladší část jejich intencionální výplně (tj. bez planýrek vyplňujících prosedlinu po sesedající se výplni) vznikla v období třicetileté války. Všechny uvedené domy byly právovárečné, vaření piva však v nálezovém obsahu svou stopu nezanechalo. Pouze v př́ípadě jediného domu (čp. 15/I) známe řemeslo jeho majitelů (kožešník Tomáš Bobrovský, vlastník v období 1614 - před 1632, a švec Jan Krejčí, vlastník 1711-1721). Na dvorku domu čp. 15/I byl prozkoumán zbytek odpadní jámy s obsahem zvířecích kostí, které nasvědčují, že byly odpadem při stahování kůží. Teprve detailní rozbor může potvrdit, zda obsah jámy spadá do doby, kdy zde působil Tomáš Bobrovský. Další odpadní jáma je datována do 18. století. $\mathrm{V}$ jejím obsahu byla mimo jiné část špatně dochované boty (?). Zde se přímá souvislost $\mathrm{s}$ Janem Krejčím zdá být velmi volná. Celkově však obsah jímek naznačuje přičinu tak velkého zpustošení za třicetileté války. Do jímek odhazovali nepotřebné věci velmi dobře situovaní měšt’ané, kteří získávali a užívali množství luxusních předmětů a mohli si je obstarat pomocí obchodních kontaktů, někdy z velmi vzdálených oblastí (čínský porcelán, benátské sklo, holandské dýmky apod.). Tento obraz je v souladu s názvem zdejší městské čtvrti, označené jako Bohatá.

Další doklady měštanské zástavby jsme měli možnost prozkoumat na tehdejším Novoměstském předměstí v areálu zahrad kapucínského kláštera. Klášterní zahrady (obr. 7:2) při komplexu kapucínského kláštera u kostela sv. Josefa na východní straně chrudimské ostrožny se nalézají v prř́mém sousedství opevněného jádra města. Vlastní kostel byl založen do prostoru druhého městského př́íkopu, který vznikl na počátku 15. století, což ovlivnilo jeho orientaci v ose sever-jih. Ostatní budovy konventu se nalézají za městským př́kopem v prostoru 


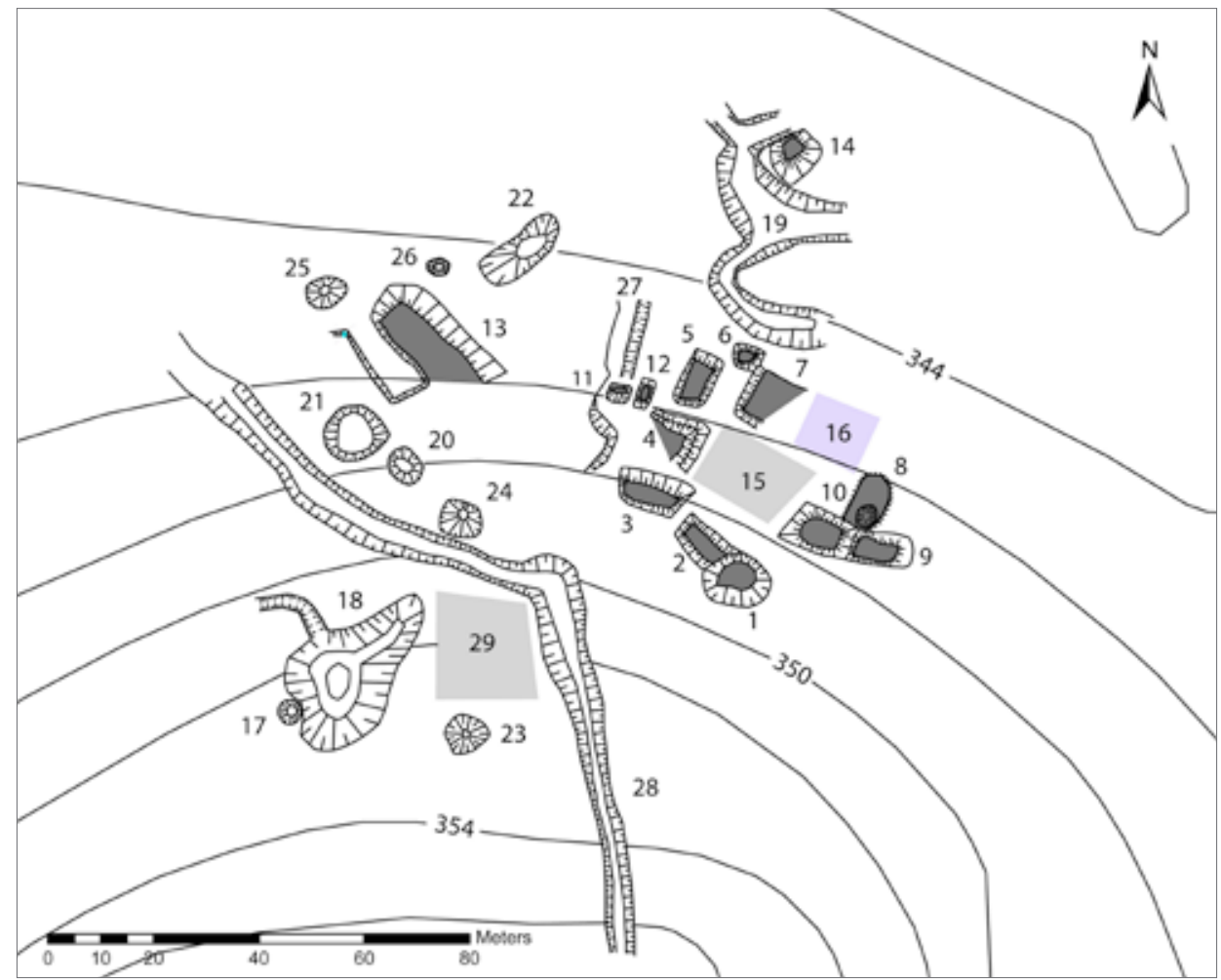

Obr. 13. Zaniklá ves a dvůr Bolešov (k. ú. Spačice, okr. Chrudim). Podle Musil-Netolický 2012.

Abb. 13. Dorfwüstung und Hof Bolešov (Katastergebiet Spačice, Bezirk Chrudim). Nach Musil-Netolický 2012.

Novoměstského předměstí, které zdevastovaly ničivé požáry a třicetiletá válka. Obnoveno bylo až koncem 18. století. Ve výkopu pro tlakovou kanalizaci bylo zjištěno torzo zděného domu zaniklého za třicetileté války a k němu náležící dvě odpadní jámy (obr. 12). Ve výplni odpadních jam byly registrovány zlomky kamenin okruhu Triebel/Muskau a habánská fajáns. V rýze pro elektrické kabelové vedení a osvětlení byla nalezena další odpadní jímka náležící k jinému domu (Musil 2009; Charvátová 2012).

Další doklad vojenských událostí ve městě představují pozůstatky vojenského tábora v poloze Švédské šance (obr. 7:3). Při stavbě sídliště v letech 1985 a 1986 zde byl realizován záchranný archeologický výzkum vedený V. Vokolkem. Výzkum je bohužel publikován pouze formou zpráv a hlášení (Vokolek 1986; 1986a; 1987), komplexně publikováno bylo doposud pouze lengyelské hradiště (Vokolek-Zápotocký 2009, 576-578). Situace na lokalitě je poměrně složitá. Pod slezskoplatěnickým hradištěm ve výrazné terénní poloze se na jeho jihovýchodní straně nalézal jazykovitý útvar s výběžkem na jižní straně. Tento útvar byl prozkoumán sítí třinácti sond (I-XIII). Při výzkumu byl dokumentován menší př́íkop se žlabem ve dně (obj. 55/85 a 63/86). V severozápadní části sondy III/1985 byla zdokumentována jeho menší část - obj. 55 (Vokolek 1986a, 53). Další pokračování bylo objeveno v sondě VI/86 - obj. 63 (Vokolek 1986, 2-3, 6; 1987). Pravidelný př́kop probíhal sondami ve směru východ-západ, na východní straně sondy VI/86 byly zjištěny pozvolna sklánějící se stěny. Při západní stěně byl registrován $1,06-1,23 \mathrm{~m}$ hluboký žlab po palisádě o šířce $1,3-1,4 \mathrm{~m}$. Ve dně o šířce $0,8 \mathrm{~m}$ byl ještě vyhlouben úzký, $0,3 \mathrm{~m}$ široký žlábek (Vokolek 1987, 31). Podle pozorování V. Vokolka př́ikop patrně ohraničoval větší 
část návrší a pokračoval i na poli východně od pravěkého hradiště. Tomu nasvědčovala i v té době patrná konfigurace terénu na jižním konci návrší, kde byla vybudována téměř kruhová plošina ohraničená příkopem, druhotně užívaným jako úvozová cesta. Tato plošina mohla sloužit jako dělostřelecká reduta kontrolující příchod k městu od Vysokého Mýta (srov. Vokolek 1987, 36). Není bez zajímavosti, že jedna z největších koncentrací výše popisovaných nášivek ve tvaru lva $(6 \mathrm{ks})$ se nalézá $1,5 \mathrm{~km}$ jižněji, v přímé viditelnosti z tohoto postavení.

\section{Vesnice}

Během vojenských operací v první polovině 17. století na Chrudimsku zaniklo celkem čtrnáct vsí, které již nebyly obnoveny. ${ }^{2}$ Asi nejlépe poznaný př́ípad představuje ves Bolešov (k. ú. Spačice; obr. 13 - základní informace viz Musil-Netolický 2012). Bolešov představuje zástupce středověké vsi zredukované postupem času na pouhý poplužní dvůr. Relikty se nalézají na zalesněném jižně exponovaném svahu v trati Dubina v nadmořské výšce 346,0-348,0 m. Počátky osídlení oblasti je možné klást již do 12. století. První písemná zmínka o vsi Bolešov pochází až z roku 1491 (RT II, 449; srov. Sedláček 1900, 38). Při prodeji panství v roce 1539 je Bolešov zmiňován pouze jako dvůr (Sedláček 1900, 38 a 46), ale v letech 1544 (Profous 1947, 112), 1557 a 1586 jako ves (Sedláček 1900, 46). Na sklonku 16. století zde tedy existovala ještě vesnice (patrně menší), ale již roku 1623 je zmiňován pouze dvůr. V dokumentu z roku 1654 již není o Bolešově žádná zmínka (Sedláček 1900, 46). Je tedy zřejmé, že Bolešov zanikl v průběhu třicetileté války.

Doposud jedinou dokumentovanou lokalitou, která snese porovnání s objevenými terénními pozůstatky vsi/dvora Bolešova, je zaniklý poplužní dvůr Nevězeň na Rokycansku (Vařeka et al. 2008, 117-126) nebo zaniklá časně novověká ves Bukov (Vařeka 2016, 156-167). Z poznatků získaných pouze povrchovým průzkumem lokality Bolešov, bez archeologického odkryvu, nelze jednoznačně určit charakter a datování jednotlivých objektů. Obecně lze konstatovat, že Bolešov byl $\mathrm{v}$ průběhu své existence tvořen pouze dvěma až třemi usedlostmi, které se snad v průběhu 15. či 16. století transformovaly v poplužní dvůr.

Další vsí zaniklou za třicetileté války jsou Drbohlavy. První zmínku o Drbohlavech nacházíme až v berní rule z roku 1654, kdy je uváděna jako pustá. Patrně splynula se sousední žijící vsí Bošovem (Klaus et al. 1926, 212-213; Roubík 1959, 111; Svoboda-Šmilauer 1960, 370).

V tomto období zanikly rovněž Hody (Zhody, k. ú. Vyžice), poprvé připomínané v roce 1382. Berní rula ves uvádí k roku 1654 jako zcela pustou. V roce 1713 je uváděno, že na místě vsi vznikl vrchnostenský dvůr, plužiny jsou zmiňovány jako „,von Hof zu den Hoden, hinten auf den Hoden“. Ves není doposud zcela spolehlivě lokalizována. Lesní trat’ V Hodech se nalézá severně od intravilánu obce Slavkovice. Rozsáhlý lesní komplex odvodňují dvě vodoteče, na nichž registrujeme zaniklé rybníky. Podle svědectví z roku 1713 je to ale místo hospodářského zázemí vsi. Vlastní zástavba doposud nebyla objevena (Klaus et al. 1926, 212, 486; Profous 1947, 581-582; Roubík 1959, 111; Svoboda-Šmilauer 1960, 381; Teplý 1991, 13-48).

Poněkud komplikovaný vývoj sídlištní dynamiky má ves Lipina, poprvé připomínaná k roku 1457 v souvislosti s rabštejnským panstvím (AČ III, 555; Klaus et al. 1926, 421). Znovu je připomínaná v letech 1464 (Teplý 1997, 18-79), 1540 (Klaus et al. 1926, 421) a 1547 (Profous 1949, 623). Lipina zanikla v průběhu třicetileté války, takže v berní rule je uváděna jako pustá. Znovu obnovena byla až v 18. století (Profous 1949, 623; Roubík 1959, 111; Šulc 2001, 216).

Zcela beze zbytku zanikla ves Luhy (k. ú. Březinka u Hoštalovic), poprvé připomínaná v roce 1560. Poslední zmínky o vsi pochází z roku 1623, přičemž berní rula ji už neuvádí. Podle F. Roubíka $(1959,115)$ ležela ves Luhy poblíž Choltic. Nicméně již ve 20. letech 20. století byly její pozůstatky identifikovány v sousedství tvrziště Stoupec (Sedláček 1866-1867, 561-564; Birnbaumová-Jansová 1929, 48).

2 Vesnice Dolina, Tasovice, Slavkovice, Vlastějov a Boukalka zaniklé během třicetileté války byly ještě během 17. století znovuobnoveny (Klaus et al. 1926, 212). Ves Boukalku zničil bez jakékoliv dokumentace ve 20. století vápencový lom v Prachovicích. Ves Lipina byla znovu vyměřena až v 18 . století. 
Relativně krátké období existence měla i ves Máslovanky (k. ú. Horní Bradlo?), která je poprvé připomínaná roku 1617. Další zmínka pak pochází z roku 1637 v souvislosti s tvrzí Modletín. Berní rula k roku 1654 ji uvádí jako pustou. Vesnice Máslovanky se nalézala poblíž Lipky, severně od Modletína a jihozápadně od Nasavrk (Profous 1951, 35; Roubík 1959, 110; SvobodaŠmilauer 1960, 380).

Lokalizace vsi Mrdice (k. ú. Heřmanův Městec) nečiní žádné obtíže. Vesnice spolu se stejnojmennou tvrzí a poplužním dvorem se nalézá v lese Bažantnice při silnici z Heřmanova Městce do Klešic. První písemná zmínka o tvrzi a přilehlé vsi pochází z roku 1318, další zpráva pochází z roku 1398. Celý komplex zanikl za třicetileté války a již nebyl obnoven (Profous 1951, 145; Svoboda-Šmilauer 1960, 382).

Za třicetileté války zanikla také menší ves Písky ležící na cestě mezi Markovicemi a Morašicemi. Ves je poprvé připomínána roku 1429, na přelomu 16. a 17. století byla tvořena jen dvěma usedlostmi (Klaus et al. 1926, 213).

Osada Svatý Mikuláš (se stejnojmenným středověkým kostelem) u Rváčova měla podobný vývoj jako výše uvedená Lipina. Poprvé je osada s kostelem připomínána roku 1350 v souvislosti s vymezováním hranic nově vzniklého litomyšlského biskupství (MV I, 701). Berní rula ji uvádí jako pustou, jen s existujícím kostelem. V 18. století zde byla založena nová vesnice, která se rozsahem patrně kryje s původní středověkou vsí (Profous 1951, 70; Roubík 1959, 109; Šulc 2001, 236).

V první polovině 17. století zanikl život i v prostoru vsi Stusyně (k. ú. Ronov nad Doubravou) s centrálním bodem, který představuje románský kostel sv. Martina. Právě okolo něj vznikla ve 12. století vesnice. První písemná zmínka pochází až z roku 1352. Roku 1578 je připomínán pouze mlýn, který zanikl za třicetileté války. Spolu s protilehlou vsí Protivany (Protivenice) při kostele svatého Kř́žze ležely u brodu přes řeku Doubravu. Na sklonku 70. let 20. století zde prováděli povrchový průzkum Z. Smetánka (Smetánka 1977) a J. Škabrada. Nálezy jsou však dnes nezvěstné. Zaniklá ves se nalézala na poli vymezeném silnicí a vodním tokem naproti kostelu sv. Martina. Mimo kostela a hřbitova je zde patrný svazek úvozových cest vedoucí k brodu přes Doubravu a náhon k mlýnu, připomínanému v roce 1578 (Profous-Svoboda 1957, 226; Roubík 1959, 108; Svoboda-Šmilauer 1960, 354; Smetánka-Škabrada 1975, 262-266; 1977, 105-112; Smetánka 1987, 242).

V sousedství Ronova nad Doubravou se nalézala i tvrz Suchotlesky (k. ú. Ronov nad Doubravou) s přilehlým hospodářským zázemím v podobě rybníků, mlýna, hospodářského dvora a vesnice. Počátky Suchotlesk u Ronova nad Doubravou dostupné písemné prameny př́liš neosvětlují. První spolehlivé zmínky pocházejí až z 16. století. Nutno předeslat, že dispozice zdejší tvrze poukazuje na středověké založení. Podle A. Sedláčka $(1909,848)$ náležely Suchotlesky původně k majetku vilémovského kláštera, poté k lichtenburskému panství (k rekonstrukci klášterních držav srov. zejm. Somer-Šrámek 2010, 16-38, Mapa 1). Další nepřímý důkaz někdejší klášterní držby bychom mohli spatřovat v držbě Trčků z Lípy. Statky vilémovského kláštera zničeného v roce 1421 při husitském tažení do východních Čech připadly dílem Janu Hertvíkovi z Rušinova, dílem Trčkům z Lípy (srov. Somer-Šrámek 2010, 41). Suchotlesky Trčkům náležely výslovně do roku 1557, kdy je odkoupil Albrecht Robmháp ze Suché. Jeho vnuk Albrecht starší zůstal své víře věrný, a proto po obnoveném zřízení zemském roku 1627 emigroval. Suchotlesky koupil Jan Rudolf Trčka z Lípy, který je držel až do svého osudového pádu roku 1634 (Sedláček 1900a, 45-46). Jeho majetek byl konfiskován v roce 1636. V soupisu je uváděna tvrz Suchotlesky s poplužním dvorem se 4,5 lány polí, 12 koňmi, 37 kusy hovězího dobytka a 180 ovcemi (Bílek 1883, 688). Jedná se o poslední písemnou zmínku o existenci tvrze tohoto jména, sama ves zanikla v průběhu třicetileté války. Dle soupisu poddaných podle víry z roku 1651 už existoval pouze hospodářský dvůr s devíti osobami. K tomuto dvoru náležely nejen plužiny někdejší vsi Suchotlesky, ale byla k němu připojena i část plužiny zaniklé vsi Stusyně (Zahradníková-Šreinová 1999, 406, 419). Poslední zmínka o existenci už jen samostatného dvora pochází z roku 1727 (Čermák 1882-1884, 238). Lokalizace tvrziště, zaniklé vsi a přilehlého dvora nečiní v zásadě žádné obtíže. Poměrně dobře patrné relikty se nalézají na jihovýchodním 
okraji intravilánu města, na pravém břehu potoka protékajícího hájkem Bažantnice, nad třemi rybníčky (Culek 1958, 47-52).

V prostoru mezi Trojovicemi a Vejvanovicemi východně od Chrudimi se nalézala ves Třtí (Tři). První písemná zmínka o vsi tohoto jména pochází z roku 1371 (RT I, 440). Poslední stopou v písemných pramenech je rok 1548. Ves patrně zanikla během třicetileté války, berní rula ji již neuvádí (Klaus et al. 1926, 258; Profous-Svoboda 1957, 388; Roubík 1959, 111; Svoboda-Šmilauer 1960, 382).

Ještě méně informací máme o vsi Záhuby (k. ú. Jetonice?). Jediná informace o existenci vsi tohoto jména pochází z roku 1622. Ves patrně zanikla během třicetileté války, v pozdějších pramenech se již nevyskytuje. F. Roubík $(1959,108)$ ji klade poblíž rybníka u Jetonic.

Pohnutý osud měla i vesnice Zlatník (též Zlatušov, Zlatnice, k. ú. Hrbokov, mlýn Dolánky). Ves je poprvé zaznamenána $v$ majetku rodu $\mathrm{z}$ Mrdic v roce 1382. Připomínána je ještě v letech 1578 a 1584 . Ves zanikla během třicetileté války. V roce 1656 se uvádí jako pustá. Urbáŕ heřmanoměsteckého panství z druhé poloviny 17. století uvádí jen zanikající rybníky. Ty byly pouze částečně využity (minimálně jeden zanikl) mlýnem Dolánky (srov. Musil-Netolický 2013). Upozorněním na existenci této vsi je poloha U Zlatníka, kde ale patrně byly pouze plužiny. Ves samotná se patrně nalézala v prostoru nízké smrčiny asi $0,2 \mathrm{~km}$ severně od mlýna Dolánky. V lese jsou patrné úvozové cesty, relikt hráze původního rybníka a terasovité úpravy (Klaus et al. 1926, 212-213, 486-487; Profous-Svoboda 1957, 779-780; Svoboda-Šmilauer 1960, 382; Teplý 1997, 38; Musil-Netolický 2013).

Výzkum zaniklých vsí na Chrudimsku doplňujeme o poznatek z bezprostředního okolí Hradce Králové, kde zatím pozorujeme horní hranici distribuce vojenských spínadel. Jde o nález zaniklé venkovské usedlosti či dvora na písečné vyvýšenině nad místní vodotečí na okraji Roudnice. Povrchovým průzkumem a za použití detektoru kovu se zde Janu Skalovi z Muzea východních Čech v Hradci Králové podařilo sesbírat množství zlomků raně novověké keramiky, mezi nimiž převažují zlomky hrnců, džbánů, trojnožek, mis, mis s plastickými lištami (řetízkování v kombinaci s nehtovými vrypy) a malovaných mis s talířovitým podokrajím. Dva zlomky kamenin z produkčních center Tribel-Muskau a Westerwald svědčí o distribuci tohoto německého zboží na východočeský venkov. Keramickou kolekci doplňují nálezy fragmentů renesančních komorových kachlů, mezi nimiž pozorujeme režné kusy s figurálními a vegetabilními motivy a zeleně polévané kachle s medailonem. V nálezech skla nechybí zlomky okenních terčů. Další skupinu tvoří kusy strusky a kovové artefakty z bronzu a železa, zejména zaujme ozdobné kování, kování knihy, knoflík. Soubor artefaktů datuje existenci dvora do 15. až první poloviny 17. století. Zánik za třicetileté války datuje několik drobných stř́ibrných mincí, které pochází ze sklonku 16. století.

\section{Depoty}

Předmětem následující stati není podat vyčerpávající přehled mincovních depotů z vymezené oblasti, nýbrž pouze nastínit prostorovou distribuci mincovních depotů datovaných do třicetileté války, které byly publikovány v odborné literatuře. Zároveň nebude detailně řešena jejich numismatická skladba.

Z období českého stavovského povstání sledujeme na Chrudimsku a v jeho těsném okolí celou řadu depotů. Po roce 1619 byl v koženém váčku uložen depot 124 mincí ve Starých Ždánicích na Pardubicku. Složen byl výhradně z habsburských ražeb Ferdinanda I., Maxmilána II., Rudolfa II. a Matyáše (Nohejlová-Prátová 1957, 57). V roce 1824 se při rozvážení hlíny na pastvině u Chvaletic podařilo objevit hliněnou nádobku, která obsahovala 1153 mincí uložených po roce 1620 (Nohejlová-Prátová 1957, 60-61). Po roce 1620 byl uložen v nádobě také depot 168 stř́ibrných mincí objevený v Býšti u Holic (Nohejlová-Prátová 1957, 60). Po roce 1621 je pak datován depot mincí, jež se podařilo postupně sesbírat při rovnání pozemku u čp. 13 ve vsi Břehy u Přelouče (Nohejlová-Prátová 1957, 66). Celkem šlo o 311 mincí. V téže době byl do 
země zřejmě umístěn i mincovní depot, který byl objeven při kopání na zahradě jednoho z domů v Kojicích v roce 1932 (Nohejlová-Prátová 1957, 67).

Další depoty byly do země ukládány ve 20 . letech 17 . století, kdy protestantské obyvatelstvo utíkalo do exilu a oblast byla postupně rekatolizována. Kolem roku 1624 byly uschovány mince u Dolního Holetína (Nohejlová-Prátová 1957, 75). Z nich se v roce 1929 podařilo zachytit 38 kusů. Na Hlinecku byl uložen také mincovní poklad u Chlumětína. Tentokrát šlo o mince uložené v nádobě po roce 1627 (Nohejlová-Prátová 1957, 82). Po roce 1628 byl pak uschován depot mincí na Podhůře u Chrudimi (Nohejlová-Prátová 1957, 84). Kolem téhož roku byl uložen také depot v Licomělicích, který byl objeven na zahradě domu čp. 19. Šlo o více než 300 mincí - z Čech, Slezska, Polska, Rakous, Tyrol, Korutan, Bavorska, Falce, Nassavska, Štrasburku, Waldecka, Východního Fríska atd. (Nohejlová-Prátová 1957, 85; Smolík 1908, 249-254).

Ze 30. let 17. století pochází depot uložený opět v obci Břehy, tentokrát byl soubor 635 zlatých a 16 stř́ibrných získán při melioraci na mlýnské louce (Nohejlová-Prátová 1957, 87). Kolem roku 1631 bylo schováno 87 stř́ibrných mincí u Ronova nad Doubravou (Nohejlová-Prátová 1957, 91). Po roce 1632 byl uložen do základového zdiva jednoho z domů v Nedělišti u Hradce Králové depot čítající 26 mincí. Podařilo se je objevit při úklidu požářiště (Nohejlová-Prátová 1957, 93). V Heřmanově Městci byl při kopání pod hrušní objeven nizozemský dukát z roku 1634 (Nohejlová-Prátová 1957, 96). Mince Ferdinanda II. z roku 1637 byla objevena v Licoměřicích (Nohejlová-Prátová 1957, 103). V téže době byl uložen v lese na Králově hoře u Slatiňan soubor 300 stříbrných mincí Rudolfa II. a Ferdinanda II. Habsbruského v plátěném obalu (Nohejlová-Prátová 1957, 104). Kolem roku 1638 byl do země uložen další nově objevený depot v Licoměřicích a po roce 1639 byl uschován poklad pěti stříbrných mincí ve sklepě domu v Hradební ulici v Chrudimi (srov. výše).

Po roce 1641 byl uložen depot o neznámém počtu mincí, z nichž bylo popsáno 67 kusů, u Samařova na Chrudimsku (Nohejlová-Prátová 1957, 110). Po roce 1644 byl uložen depot v nádobě v Zádolí u Vysokého Mýta, který obsahoval 546 zlatých a stř́ibrných mincí (Nohejlová-Prátová 1957, 113).

Bez bližší datace známe další depot 12 mincí z Chlumce nad Cidlinou, který obsahoval mimo jiné dukát Ferdindanda II. z roku 1635 (Nohejlová-Prátová 1957, 121). V témže městě byl v roce 1934 objeven i další soubor 1100 zlatých a stříbrných mincí datovaných do období tř́icetileté války. Neznámý počet mincí, z nichž byly popsány dva kusy, pochází z domu u Blumenkranzů v Chrudimi. Tento depot obsahoval tř́íkrejcar Jindřicha Šlika (Čechy) z roku 1637 a minci Ferdinanda II. (Slezsko). Neznámé počty mincí byly objeveny také v základech domu u Nového divadla, kde byly objeveny dva tř́krejcary Ferdinanda II. z roku 1639, a další depot, z něhož víme o dvou mincích Ferdinanda II., pochází z Urnového háje (Nohejlová-Prátová 1957, 121-122). „Trochu“ stř́ibrných mincí z doby krále Matyáše II. a pozdější bylo objeveno v nádobě na zahradě domu čp. 17 ve Volči (Nohejlová-Prátová 1957, 132).

Dle složení mincovních depotů lze částečně nastínit, kdo v době třicetileté války depoty ukrýval. Šlo zejména o domácí obyvatelstvo, které se cítilo ohroženo. Do této kategorie, v níž výrazně převažují domácí mince, patří depoty ze Starých Ždánic, Chvaletic (vedle středoevropských mincí nechybí mince severních mincoven z Brém, Saska, Pruska, Polska, Litvy aj.), Býště u Holic, Břehů, Dolního Holetína, Chlumětína (mimo převažující domácí mince zde byly mince z oblasti Nizozemí, Benátek, Savojska, Turecka), Chrudimi-Podhůry, Licomělic, Neděliště, Slatiňan, Zádolí (mimo domácí mince zejména mince nizozemské), Chlumce nad Cidlinou, Chrudimi, Samařova, Volče ad. Mezi žoldnéřské depoty lze snad zařadit pouze poklad z Kojic, který obsahoval výhradně cizí měnu, v níž převažovaly mince německých států.

\section{Závěr}

Jak vyplývá ze současného stavu poznání období třicetileté války ve východočeském prostoru (konkrétně na Chrudimsku a Pardubicku), jedná se o region s velkým informačním potenciálem. Ačkoliv na Chrudimsku a Pardubicku na rozdíl od západočeského či jihomoravského 
prostoru chybí hmotné doklady velkých bojišt' nebo pozůstatků obléhacích prací, můžeme zde díky tranzitní pozici sledovaného území poměrně dobře dokumentovat např́íklad změny venkovského osídlení, výrazné destrukční horizonty ve městech - doplňované nálezy keramických dýmek a pohyby menších vojenských kontingentů doplněné dislokací známých mincovních depotů.

Tento článek byl podpořen grantem GAČR: GA15-03380S: Proměněná země. Interdisciplinární výzkum vlivu třicetileté války na venkovskou krajinu Čech (2015-2017).

\section{Prameny a literatura}

AČ III: Archiv český čili staré písemné památky české i morawské z archivůw domácích i cizích III (Palacký, F., ed.). Praha 1844.

AČ XXXI: Archiv český čili staré písemní památky české i moravské. Díl XXXI (Fridrich, G., ed.). Praha 1935.

ARTICUS, R. J. J., 1990: Vom Rauchen und den Tabakpfeifenmachern in Schleswig-Holstein, Knasterkopf $2,11-36$.

- 1997: Wie die Tonpfeifen in die Lünebruger Heide kamen, Knasterkopf 8, 4-44.

BERGER, T.-MALÝ, T., 2005: „Historya Chrudimska w niž sewipisuje počátek Města Chrudimě...“. 2. svazek. Přepis originálu rukopisu Josefa Ceregettiho z roku 1771 s komentářem. Chrudim.

BÍLEK, T. V., 1883: Dějiny konfiskací v Čechách po roce 1618. Část druhá. Praha.

BIRNBAUMOVÁ, A.-JANSOVÁ, L., 1929: Soupis památek historických a uměleckých v politickém okresu Čáslavském. Praha.

BOSSEN, C., 2006: War as Practice, Power, and Processor: A Framework for the Analysis of War and Social Structural Change. In: Warfare and Society. Archaeological and Social Anthropological Perspectives (Otto, T.-Thrane, H.-Vandkilde, H., edd.), 89-102. Aarhus.

CULEK, A., 1958: Drobné př́spěvky k dějinám města Ronova n. Doubravou, Pardubický kraj II, 47-52.

ČADKOVÁ, I.-ZAHRADNÍKOVÁ, M., (edd.) 2011: Berní rula 15. Kraj Hradecký IV. Praha.

ČERMÁK, K., 1882-1884: Kde hledati jest Suchotlesky?, Památky archaeologické a místopisné XII, 238-239.

ČESENEK, L., 1969-1970: Nález mincí z 30leté války v Pardubicích, Numismatický sborník 11, 199-200.

DUCO, D. H., 1982: Merken van Goudse pijpenmakers 1660-1940. Lochem.

- 1987: De nederlandse kleipijp. Handboek voor dateren en determineren. Leiden.

DVORSKÝ, F., 1882: O počtu domů v Praze a v královských městech v Čechách v 16.-19. století. Praha.

EICKHOFF, S.-GROTHE, A.-JUNGKLAUS, B., 2012: 1636. Ihre letzte Schlacht. Berlin.

FALTYSOVÁ, H.-BÁRTA, F. et al., 2002: Pardubicko. Chráněná krajinná území ČR. Svazek IV (Mackovčin, P.-Sedláček, M., edd.). Praha.

FLORIÁN, Č., s. d.: Topografie Chrudimi I. Rukopis. Uloženo v SOkA Chrudim, fond Pozůstalost Vincence Floriána, kart. 1, inv. č. 16.

FOARD, G., 2012: Battlefield Archaeology of the English Civil War. Oxford.

FROLÍK, J.-MUSIL, J., 2010: Záchranný archeologický výzkum v Hradební ulici v Chrudimi v roce 2006, Chrudimský vlastivědný sborník 14, 3-28.

FROLÍK, J.-SMETÁNKA, Z., 1997: Archeologie na Pražském hradě. Praha - Litomyšl.

HOCKER, F., 2012: Vasa. Stockholm.

HOLČÍK, Š., 1984: Fajky. Bratislava.

CHARVÁTOVÁ, A., 2012: Novoměstské předměstí v Chrudimi na základě archeologických nálezů. Nepublikovaná bakalářská práce, ulož. v Ústavu historických věd Filozofické fakulty Univerzity Pardubice.

CHRÁSKA, P. J., ed., 1945: Komenský, J. A. 1632: Polnice milostivého léta pro národ český. Zvěstující zarmouceným potěšení, lkajícím radost, zajatým vysvobození, rozptýleným shromáždění. Kutná Hora.

JANÁK, J.-HLEDÍKOVÁ, Z., 1989: Dějiny správy v českých zemích do roku 1945. Praha.

KALESNÝ, F., 1981: Habáni na Slovensku. Bratislava.

KLAUS, A. et al., 1926: Chrudimsko a Nasavrcko IV. Prehistorie a historie obcí na Chrudimsku. Chrudim.

KLUTTIG-ALTMANN, R., 2005: Tonpfeifenfunde im südlichen Ostseeraum und in Schlesien - Erste Ergebnisse einer internationalen Ausstellung im Ostpreußischen Landesmuseum Lüneburg, Knasterkopf $18,17-25$. 
KLUTTIG-ALTMANN, R.-MEHLER, N., 2007: Die Emanzipation der deutschen Tonpfeifenforschung. Frühe deutsche Tonpfeifenproduktion im 17. Jahrhundert, Mitteilungen der Deutschen Gesellschaft für Archäologie des Mittelalters und der Neuzeit 18, 71-80.

LÍVA, V., 1954: Prameny k dějinám třicetileté války. Regesta fondu Militare Archivu Ministerstva vnitra ČSR v Praze. Díl V. 1636-1639. Praha.

- 1955: Prameny k dějinám třicetileté války. Regesta fondu Militare Archivu Ministerstva vnitra ČSR v Praze. Díl VII. 1643-1645. Praha.

- 1957: Prameny k dějinám třicetileté války. Regesta fondu Militare Archivu Ministerstva vnitra ČSR v Praze. Díl VIII. 1646-1648. Praha.

MALÝ, K.-SIVÁK, F., 1993: Dějiny státu a práva v českých zemích a na Slovensku 1. Jinočany.

MATUŠÍKOVÁ, L.-PAZDEROVÁ, A., edd., 2001: Soupis poddaných podle víry z roku 1651. Chrudimsko 1-3. Praha.

VAN DER MEULEN, J., 1994: De „gekroonde roos“ en andere pijpenmakersmerken van Gouda. Leiden.

MUSIL, J., 2009: Zpráva o záchranném archeologickém výzkumu provedeném na základě dohody č. 37/09 na lokalitě Chrudim, akce: Rekonstrukce klášterních zahrad. Nálezová zpráva, ulož. v Regionálním muzeu v Chrudimi.

- 2010: Soubor raně novověkých hliněných dýmek z Hradební ulice v Chrudimi - Eine Kollektion neuzeitlicher Tonpfeifen aus der Hradební-Gasse in Chrudim. In: Zaměřeno na středověk. Zdeňkovi Měřínskému k 60. narozeninám (Ungerman, Š.-Přichystalová, R.-Šulc, M.-Krejsová, J., edd.), 509-526. Praha.

- 2010a: Nález raně novověké prachovnice z Chrudimi - Hradební ulice - Find of Early Modern era powder flask from Chrudim - Hradební Street, Východočeský sborník historický 18, 85-92.

- 2013: Nášivka ve tvaru lvíčka z k. ú. Bylany, Chrudimské vlastivědné listy, 15-17.

- 2016: Zpráva o záchranném archeologickém výzkumu provedeném na základě dohody č. 102/2016 na lokalitě Chrudim, Břetislavova ul., akce: MLK - rekonstrukce teras; Břetislavova 74 (IDAV: 67867), ulož. v Regionálním muzeu v Chrudimi.

MUSIL, J.-NETOLICKÝ, P., 2012: Zaniklá středověká a raně novověká ves Bolešov v k. ú. Spačice, okres Chrudim, Pardubický kraj - The perished medieval and early-modern-age village of Bolešov in the cadastral territory of Spačice, district of Chrudim, the Pardubice region, Východočeský sborník historický 22, 73-114.

- 2013: Studium dynamiky středověkých sídelních struktur v tzv. bojanovském újezdu (Železné hory, okres Chrudim) - Studying the dynamic of medieval settlement structures in the Bojanov's district, Živá archeologie - REA 15/1, 32-37.

MV I: Monumenta vaticana I. Acta Clementis VI. Pontificis romani 1342-1352 (Klicman, L., ed.). Pragae 1903.

NOHEJLOVÁ-PRÁTOVÁ, E., 1957: Nálezy mincí v Čechách, na Moravě a ve Slezsku III. Praha.

NOVÁK, D.-VǍ̌EKA, P., 2016: A late-medieval manor farm in Rovný (Rokycany district, Pilsen region), AH 41, 211-227.

NOVOTNÁ, L., 2013: Příspěvek k dějinám Chrudimi za třicetileté války - léta 1639-1648. Nepublikovaná bakalářská práce, ulož. v Ústavu historických věd Filozofické fakulty Univerzity Pardubice.

NOVOTNÝ, V., 1937: České dějiny I. 4. Rozmach české moci za Přemysla II. Praha.

PETRTYL, J., 1963-1964: Nález grošů Ferdinanda II. v Chrudimi, Numismatický sborník 8, 251.

PITHART, P., 2010: Město v soukolí válečného stroje. Historie města Chrudimi v letech 1639-1650. Nepublikovaná bakalářská práce, ulož. v Ústavu historických věd Filozofické fakulty Univerzity Pardubice.

PREUSZ, M., 2017: Zlaté rouno z bronzu. Katolický vojenský přívěsek z bojiště u Rozvadova/Waidhausu 1621 - The Bronze Golden Fleece. Catholic military pendant from the battlefield Rozvadov/Waidhaus 1621, AZČ 12, 170-186.

PROFOUS, A., 1947: Místní jména v Čechách. Jejich vznik, původní význam a změny. Díl I. A-H. Praha.

- 1949: Místní jména v Čechách. Jejich vznik, původní význam a změny. Díl II. CH-L. Praha.

- 1951: Místní jména v Čechách. Jejich vznik, původní význam a změny. Díl III. M-̌̌̉. Praha.

PROFOUS, A.-SVOBODA, J., 1957: Místní jména v Čechách. Jejich vznik, původní význam a změny. Díl IV. S-Ž. Praha.

PROKEŠOVÁ, T., 2007: Třicetiletá válka v královském věnném městě Chrudimi. Dějiny města do prvního švédského vpádu v roce 1639. Nepublikovaná bakalářská práce, ulož. v Ústavu historických věd Filozofické fakulty Univerzity Pardubice.

RAOSB 1893: Rikskansleren Axel Oxenstiernas skrifter och brefvexling. Afd. 2. Bd. 6, Johan Banérs bref 1624-1641, Stockholm.

ROUBÍK, F., 1959: Soupis a mapa zaniklých osad v Čechách. Praha. 
RT I: Reliquiae tabularum terrae regni Bohemiae anno MDXLI igne combustarum I. (Emler, J., ed.). Pragae 1870 .

SEDLÁČEK, A., 1866-1867: Zaniklé osady v okolí Čáslavském, PA VII, 561-564.

- 1900: Hrady, zámky a tvrze království Českého. Díl I. Praha.

- 1900a: Hrady, zámky a tvrze království Českého. Díl XII. Praha.

- 1909: Místopisný slovník historický království Českého. Praha.

- 1921: O starém rozdělení Čech na kraje. Praha.

SCHÜRGER, A., 2015: The Archaeology of the Battle of Lützen: An examination of 17th century military material culture. PHD Thesis at School of Humanities, College of Arts, University of Glasgow.

SIGL, J., 1995: Předstihový výzkum v Hradební ulici čp. 14 v Chrudimi v r. 1994, Zpravodaj muzea v Hradci Králové 21, 61-72.

SMETÁNKA, Z., 1977: Nálezová zpráva - povrchový průzkum ZSO Stusyně, k. o. Ronov nad Doubravou, ulož. v Archivu nálezových zpráv, ARÚ AV ČR, v. v. i., Praha, čj. TX197702257.

- 1987: Hledání zmizelého věku. Praha.

SMETÁNKA, Z.-ŠKABRADA, J., 1975: Nové poznatky o raně středověké architektuře na Čáslavsku, Umění XXIII, 262-266.

- 1977: K počátkům městečka Ronova nad Doubravou. In: Středověká archeologie a studium počátků měst (Richter, M., ed.), 105-112. Praha.

SMOLÍK, J., 1908: Nález mincí u Vícemilic, Památky archeologické a místopisné XXIII, 249-254.

SOMER, T.-ŠRÁMEK, J., 2010: Historie benediktinského opatství sv. Petra a Pavla ve Vilémově (11601541). Praha.

SVOBODA, J., 1880: Nebeský lékař Kristus Ježíš. Kolín.

SVOBODA, J.-ŠMILAUER, V., 1960: Místní jména v Čechách. Jejich vznik, původní význam a změny. Díl V. Dodatky k dílu Antonína Profouse. Praha.

SYMONDS, J.-VǍ̌EKA, P., 2016: Paysans et soldats. Archéologie des villages de Bohême abandonnés durant la Guerre de Trente Ans. In: Violences de guerre, violences de masse (Guilaine, J.-Semelin, J., edd.), 129-145. Paris.

ŠULC, I., 2001: Soupis prvních písemných zmínek k sídlům okresu Chrudim, Chrudimský vlastivědný sborník 6, 189-246.

TEPLÝ, J., 1991: Heřmanoměstecký statek koncem 14. století, Východočeský sborník historický 1, 13-48.

- 1997: Feudální pozemková držba v předhusitském Chrudimsku. Pardubice.

THIER, B., 1990: Die Pfeifenfunde aus der Karlsburg in Bremerhaven (1672-1680), Knasterkopf 3, 1-16.

URBÁNEK, V., 2008: Eschatologie, vědění a politika. Př́íspěvek k dějinám myšlení pobělohorského exilu. České Budějovice.

VALLAŠEK, A., 1983: Dielňa na výrobu hlinených fajok na Spišskom hrade - Eine Werkstätte zur Herstellung tönerner Pfeifen auf der Burg Spišský hrad (Zipser Burg), AH 8, 168-170.

VA ̌̌EKA, P., 2008: Zaniklý dvůr Nevězeň. In: Vařeka, P. et al., Archeologie zaniklých středověkých vesnic na Rokycansku II, 117-126. Plzeň.

- 2010: Zaniklá stř̌edověká a časně novověká vesnice Vojkov na Černokostelecku - nedestruktivní výzkum, Acta Fakulty filozofické Západočeské univerzity v Plzni 4/10, 137-171.

- 2014: Zaniklá středověká a časně novověká ves Rovný na Zbirožsku (okr. Rokycany) - Das untergegangene mittelalterliche und frühneuzeitige Dorf Rovný in der Region Zbiroh (Bez. Rokycany), AZČ 7 , 131-143.

- 2016: Zaniklá středověká a časně novověká vesnice Bukov na Zbirožsku (okr. Rokycany), AZČ 10, 156-167.

VÍCH, D., Př́íspěvek k problematice detektorové prospekce v archeologii - Ein Beitrag zur Methodik der Metalldetektorprospektion in der Archäologie, AVČ 7, 152-172.

VOKOLEK, V., 1986: Chrudim „Pumberka“, ulož. v Archivu nálezových zpráv, ARÚ AV ČR, v. v. i., Praha, čj. TX198604074.

- 1986a: Výzkum v Chrudimi-Pumberkách, Zpravodaj Krajského muzea východních Čech v Hradci Králové XIII-1, 50-55.

- 1987: Archeologický výzkum v Chrudimi-Pumberkách v roce 1986, Zpravodaj Krajského muzea východních Čech v Hradci Králové XIV-1, 30-37.

VOKOLEK, V.-ZÁPOTOCKÝ, M., 2009: Východní Čechy v raném eneolitu: lengyelská a jordanovská kultura, ASČ 13, 567-654.

VORÁČEK, E. et al., 2010: Luže v dějinách. Díl 1. Luže.

- 2011: Dějiny Skutče. Skuteč. 
VOREL, P., 2002: Dějiny města Přelouče. Díl II. Přelouč.

ZAHRADNÍKOVÁ, M.-ŠREINOVÁ, E., 1999: Soupis poddaných podle víry z roku 1651. Čáslavsko 2. Praha.

\section{Internetové zdroje}

http://www.archaeologie-online.de/magazin/nachrichten/archaeologen-auf-den-spuren-des dreissigjaehrigen-krieges-15577/, cit. 8. 10. 2017.

http://www.pahor.de/augsburg-im-30-jahrigen-krieg-bildausschnitt-nach-einem-flugblatt-nach-der-einnahme-augsburgs-durch-konig-gustav-ii-adolf-von-schweden.html, cit. 2. 6. 2016.

\section{Zusammenfassung}

\section{Das archäologische Bild der Ereignisse des Dreißigjährigen Krieges in der Region Chrudim}

Der Dreißigjährige Krieg stellt den letzten der großen religiösen Konflikte zwischen Katholiken und Protestanten dar von dessen Folgen sich die Länder Böhmens dann den Rest des 17. Jahrhunderts erholten. Nicht anders war dies auch in der Region Chrudim. Für den Bedarf der hier vorgelegten Studie verstehen wir die Region Chrudim im weiteren Wortsinn als Gebiet des ehemaligen Bezirks Chrudim. Für die Zwecke dieses Beitrags erweitern wir dieses Gebiet auf die Region Pardubice und Přelouč (Abb. 1).

Vorrangiger Beleg für den Aufenthalt von Militärkontingenten in der Region Chrudim und dessen naher Umgebung im Dreißigjährigen Krieg ist eine bunte Gruppe von Kleidungsverschlüssen, die zum Verschließen und zur Dekoration von Soldatenanzügen dienten. Bei ihnen handelt es sich um Verschlüsse in Form eines gekrönten doppelköpfigen Adlers (Abb. 2) und eines gekrönten Löwen mit einer Schlange in den Pranken (Abb. 3). Beide Motive können als Kommunikationsmittel der zeitgenössischen Propaganda angesehen werden, die eng mit dem ideologischen Rahmen des Kriegskonfliktes zusammenhängen (Bossen 2006). Die Verwendung der Symbole ergibt sich aus einem evangelisch-katholischen Antagonismus, in dem sich die Eschatologie mit der politischen Aktualisierung vermischte. Mit diesem symbolischen Programm identifizierte sich besonders der schwedische König Gustav II. Adolf, der im Jahr 1630 gegen den Kaiser mit der Absicht in den Krieg eingriff, der katholischen Tyrannei den entscheidenden Schlag zu versetzen. Seine Kriegsabsichten verband er programmatisch mit dem bereits bewährten ideologischen Subtext, den er im Krieg gegen Polen verwendete. Damals stilisierte er sich selbst und das ganze schwedische Königreich zum Löwen aus Mitternacht. Es ist klar, dass die Verehrung des schwedischen Königs zu jener Zeit bei den Protestanten bereits an einen Personenkult grenzte. Die emotionsgeladene Präsentation des schwedischen Königs als Löwe aus dem Norden wurde bereits zu Beginn der dreißiger Jahre des 17. Jahrhunderts durch Kleidungsverschlüsse an der Soldatenkleidung sowie durch weitere Artefakte verbreitet. Davon zeugt der Fund einer Löwenstatuette mit Globus (Schürger 2015, 314, Abb. 23) und der Fund eines Löwenkopfes mit einer Schlange im Maul auf dem Schlachtfeld von Lützen (dort fand die Schlacht am 16. November 1632 statt). Diese wurde sogar als wahrscheinliches Bekleidungsaccessoire eines königlichen Leibgardisten interpretiert, der in der Schlacht zusammen mit dem schwedischen König gefallen war. Der Kult des wütenden Löwen aus Mitternacht wurde auch nach Gustav Adolfs Tod in der schwedischen Armee weiter verbreitet, und zwar auch trotz fehlender konkreter Führungspersönlichkeit. Ein direkter Nachweis dessen sind Funde von gekrönten Löwen mit einer Schlange in den Pranken aus einem Massengrab auf dem Schlachtfeld bei Wittstock aus dem Jahr 1636 (Eickhoff-Grothe-Jungklaus 2012, 175), weitere, sogar silberne Analogien sind auch aus einem in den dreißiger Jahren des 17. Jahrhunderts angelegten Depot von Beeskow in Brandenburg bekannt (Eickhoff-Grothe-Jungklaus 2012, 38). 
Die in den Regionen Chrudim, Pardubice und Hradec Králové entdeckten militärischen Aufnäher mit dem Motiv eines gekrönten Löwen mit Schlange (Abb. 5) weisen mehrere morphologische Varianten auf (vgl. Abb. 3). Für das Studium der Kleidungsverschlüsse wurde eine Karte des Siedlungsnetzes im ehemaligen Bezirk Chrudim und in einem Teil des Bezirks Hradec Králové erstellt (Abb. 5), die für die Region Chrudim auf einem Untertanenverzeichnis nach dem Glauben aus dem Jahr 1651 (Matušíková-Pazderová 2001) und für die Region Hradec Králové auf einer Steuerrolle aus dem Jahr 1654 (Čadková-Zahradníková 2011) basiert. Aufgrund der Kenntnis der genauen Verteilung der Kleidungsverschlüsse, die an den Stellen verloren gingen, an denen sich Soldaten aufhielten, ist der Versuch möglich, einen Bezug zwischen den einzelnen Fundstätten und den verschiedensten Natur- und Sozialfaktoren herzustellen (Abb. 5:1). Mittels dieser Bezüge versuchen wir, die strategische Landschaft, bzw. das taktische Gelände auszumachen (Foard 2012, 21-26), in dem sich die schwedische Armee bewegt hat. Die größten Fundkonzentrationen befanden sich in der Umgebung von Heřmanův Městec, Chrudim, Hrochův Týnec, Sezemice, Lázně Bohdaneč, Dražkovice sowie Holice und können auf eine Konzentration größerer Heereskorps hindeuten, die jeweiligen Funde dann auf die Verteilung kleinerer Einheiten und Patrouillen (Abb. 5:2).

Eine weitere Gruppe von Artefakten, um deren Verbreitung sich die Armeen der kämpfenden Parteien verdient gemacht haben, stellen Pfeifen dar. Die größte Gruppe an Pfeifen stammt von den in Chrudim selbst durchgeführten archäologischen Rettungsgrabungen. An dieser Stelle muss die veröffentlichte Gruppe von Pfeifen erwähnt werden, die in der dortigen Hradební-Gasse entdeckt wurde und 23 Pfeifenfragmente von 19 Exemplaren enthält.

Die archäologischen Erkenntnisse bzgl. der Städte in der Region Chrudim steht, mit Ausnahme von Chrudim, erst am Anfang. Obwohl wir wissen, dass die Städte und Kleinstädte Přelouč, Ronov nad Doubravou, Heřmanův Městec, Luže und Skuteč von den militärischen Ereignissen des Dreißigjährigen Krieges in hohem Maße betroffen waren, fehlt uns bei ihnen ein entsprechendes archäologisches Bild. In den schlichtweg meisten Fällen stoßen wir nämlich auf fehlende größerflächige Freilegungen, und wenn diese erfolgten (z.B. in Heřmanův Městec), wurden ihre Ergebnisse nicht detailliert veröffentlicht. Unsere Erkenntnisse über die Sachkultur stützen sich demnach besonders auf Chrudim, das seit den achtziger Jahren des 20. Jahrhunderts archäologisch systematisch beobachtet wurde. Der Horizont des Dreißigjährigen Krieges zeichnet sich durch einen deutlichen Eingriff in das Leben der Bewohner der untersuchten Parzellen aus und stimmt völlig mit dem Bild überein, wie es in den zeitgenössischen schriftlichen Quellen gezeichnet wurde. Während sich im Jahr 1610 in Chrudim 421 Häuser befanden, wurden von den Quellen für das Jahr 1654 in der Stadt 152 wüste Häuser und in den Vorstädten 83 erfasst (Dvorský 1882, 23). Allgemein können wir sagen, dass für den Horizont der ersten und zweiten Hälfte des 17. Jahrhunderts ein rasanter Anstieg von Stratigraphien charakteristisch ist, die überwiegend Abfall aus untergegangenen Haushalten (vgl. Musil 2016), ausgedehnte Planierschichten und Demolierungen enthalten. In den Flächen der städtischen Parzellen und auch in der Fläche des Zwingers begegnen wir einerseits ausgedehnten Stratigraphien mit einer Mächtigkeit von 1-1,5 m, und ferner sich gegenseitig störenden Abfallgruben ohne irgendeine Herrichtung der Wände. Diese Abfallgruben wurden ab dem Mittelalter durch in Stein gefasste Kloaken ersetzt. Neben architektonischen Gliedern begegnen wir einem Keramikinventar, das Steingutimitationen, in Formen ausgepresste Keramik, mit einem Kuckuck bemalte tellerförmigen Schalen u.ä. unmfasst. Das Glasinventar ist vertreten durch Trinkbecher mit halbeiförmiger oder spindelförmiger Kuppa und einem spiralförmig gedrehtem Fadenfuß, Krüge und Flaschen. Eine weitere Fundgruppe stellen kleine, häufig beschädigte Gegenstände des täglichen Bedarfs sowie Münzen dar.

Während den Militäroperationen in der ersten Hälfte des 17. Jahrhunderts wurden in der Region Chrudim definitiv insgesamt 14 Dörfer wüst, deren archäologische Untersuchung sich erst in den Anfängen befindet. Die Zusammensetzung der Funde wird um Münzdepots ergänzt. Anhand der Beschaffenheit der Münzdepots lässt sich teilweise skizzieren, wer in der Zeit des Dreißigjährigen Krieges die Depots versteckt hat. Es handelte sich besonders um die sich 
bedroht fühlende heimische Bevölkerung. Zu der Kategorie, in der heimische Münzen deutlich überwiegen, zählen die Depots aus Staré Ždánice, Chvaletice (neben mitteleuropäischen Münzen kommen auch Münzen aus nördlichen Münzstätten wie etwa Bremen, aus Sachsen, Preußen, Polen, Litauen u.a. vor), Býště bei Holice, Břehy, Dolní Holetín, Chlumětín (neben den überwiegend heimischen Münzen waren dort auch Münzen aus den Niederlanden, aus Venedig, Savoyen und der Türkei), Chlumec nad Cidlinou, Chrudim, Samařov, Voleč u.a. Zu den Söldnerdepots kann man wohl lediglich den Schatz aus Kojice zählen, der ausschließlich Münzen fremder Währungen enthielt, unter denen Münzen deutscher Staaten überwogen.

Der vorliegende Beitrag wurde vom Förderprojekt GAČR: GA15-03380S gefördert: Verwandeltes Land. Interdisziplinäre Forschung über den Einfluss des Dreißigjährigen Krieges auf die ländlichen Gegenden Böhmens (2015-2017).

PhDr. Jan Musil, Regionální muzeum v Chrudimi, Široká 86, 53701 Chrudim, Katedra archeologie Filozofické fakulty Západočeské univerzity v Plzni, Sedláčkova 15, 30614 Plzeň, Česká republika, musil@muzeumcr.cz

Mgr. Petr Netolický, Katedra archeologie Filozofické fakulty Západočeské univerzity v Plzni, Sedláčkova 15, 30614 Plzeň, Česká republika, netolicky.petr@seznam.cz

Mgr. et Mgr. Michal Preusz, Ph.D., Katedra archeologie Filozofické fakulty Západočeské univerzity v Plzni, Sedláčkova 15, 30614 Plzeň, Česká republika,preusz@kar.zcu.cz 
